\title{
Towards understanding the functional diversity of cell wall mycolic acids of Mycobacterium tuberculosis
}

\author{
Jan A. Verschoor*1 ${ }^{1}$ Mark S. Baird ${ }^{2}$ and Johan Grooten ${ }^{3}$ \\ ${ }^{1}$ Department Biochemistry, University of Pretoria, Pretoria 0002, South Africa. \\ E-mail: jan.verschoor@up.ac.za \\ ${ }^{2}$ School of Chemistry, University of Wales, Bangor LL57 2UW, United Kingdom. \\ E-mail: chs028@bangor.ac.uk \\ ${ }^{3}$ Department of Molecular Biomedical Research, Molecular Immunology Unit, University ofGent, Gent \\ 9052, Belgium. E-mail: Johan.Grooten@dmbr.UGent.be \\ *Corresponding author. Tel.: +27 12 4202477; fax: +27 123625302
}

\begin{abstract}
Mycolic acids constitute the waxy layer of the outer cell wall of Mycobacterium spp and a few other genera. They are diverse in structure, providing a unique chromatographic foot-print for almost each of the more than seventy Mycobacterium species. Although mainly esterified to cell wall arabinogalactan, trehalose or glucose, some free mycolic acid is secreted during in vitro growth of M. tuberculosis. In M. tuberculosis, alpha-, keto- and methoxy-mycolic acids are the main classes, each differing in their ability to attract neutrophils, induce foamy macrophages or adopt an antigenic structure for antibody recognition. Of interest is their particular relationship to cholesterol, discovered by their ability to attract cholesterol, to bind Amphotericin B or to be recognised by monoclonal antibodies that cross-react with cholesterol. The structural elements that determine this diverse functionality include the carboxylic acid in the mycolic motif, as well as the nature and stereochemistry of the two functional groups in the merochain. The functional diversity of mycolic acid classes implies that much information may be contained in the selective expression and secretion of mycolic acids to establish tuberculosis after infection of the host. Their cholesteroid nature may relate to how they utilize host cholesterol for their persistent survival.

Key words: Mycolic acid, cholesterol, tuberculosis, Mycobacterium, foamy macrophages, antigenicity
\end{abstract}

\section{Introduction}

It is approaching a hundred years since Anderson began to publish a ground-breaking series of papers on the isolation of novel lipid fractions from the extracts of cells of mycobacteria [1]. Within those extracts were the molecules now known as mycolic acids that have been found to show many unique and important biological properties. Mycolic acids (MAs) are long chain $\beta$-hydroxy fatty acids that can mostly be represented by the general formula $\mathbf{1}$ (Fig. 1) in which the 'mycolic motif' contains a non-functionalised long alkyl chain and the 'meromycolate chain' generally contain up to two functional groups $\mathrm{X}$ and $\mathrm{Y}$ that are described below. Mycolic acids are mainly bound to the cell wall through esters formed between the acid group and an alcohol of a sugar, often as penta-arabinose tetramycolates. They are also present as non-bound solvent extractable esters, such as trehalose monoand dimycolates (TMM and TDM), glucose monomycolate (GMM) and glycerol monomycolate, and as free mycolic acids. 


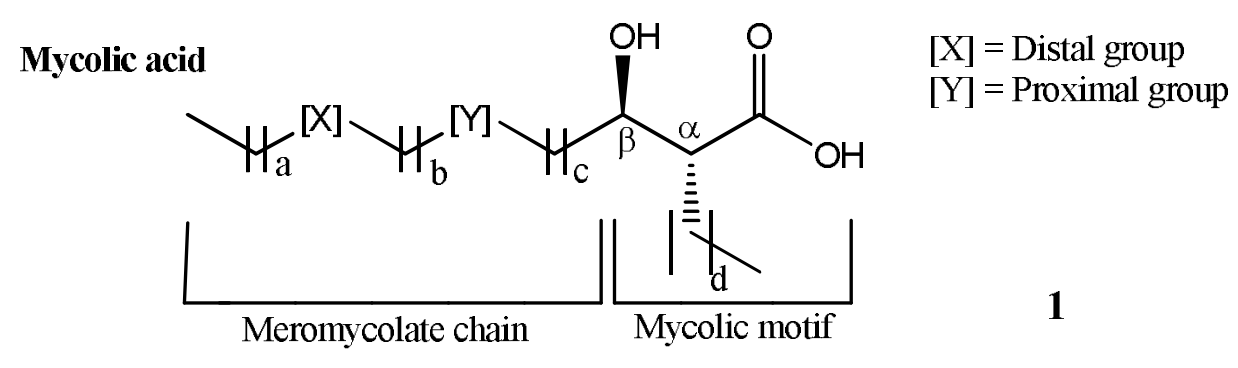

Figure 1. General structure of a mycolic acid. Varying lengths of methylene chains are indicated by a-d.

Mycolic acids occur in a distinct group of Gram-positive bacteria, classified in the suborder of Corynebacterineae, including the genera Mycobacterium, Nocardia, Rhodococcus and Corynebacterium, mentioned here in the order in which they contain large-and-complex to small-andsimple mycolic acids. In Corynebacterium the mycolic acids are smallest $\left(\mathrm{C}_{28}-\mathrm{C}_{40}\right)$ and seem only to provide a beneficial, but not life-essential permeability barrier for the exchange of nutrients and antibiotics over the cell wall [2]. In contrast, Mycobacterium species are fully dependent for growth and survival in vitro and in vivo on their mycolic acids, which are the largest $\left(\mathrm{C}_{60}-\mathrm{C}_{90}\right)$ in nature $[3,4]$. Rhodococcus has mycolic acids in the size range $\mathrm{C}_{30}-\mathrm{C}_{54}$, and Nocardia in the size range $\mathrm{C}_{42}-\mathrm{C}_{66}$ but in both cases with no functional groups in the mero-chain other than the possibility of one or more double bonds $[5,6,7,8]$.

In the pathogenic mycobacteria, such as M. tuberculosis and M. leprae, mycolic acids have distal chiral, oxygenated and proximal and/or distal chiral, non-oxygenated functional groups in the merochain defined by X and Y respectively, and different chain lengths a-d (Fig. 1), all of which seem to endow important structural properties on the mycolic acids, which determine virulence and manipulation of the host immune response to establish a host-pathogen relationship that brings about the particular disease syndrome (eg. [9]).

When considering the structure-function relationship of mycolic acids, it is important to put it into the context of the three ways that they are expressed by the mycobacteria, viz. as bound to the arabinogalactan of the cell wall, in cell wall extractable esters such as trehalose dimycolate (TDM), or secreted as the free mycolic acids. When mycobacterial mutants are prepared that produce modified mycolic acids due to genetically impaired or deleted enzymes, then their changed behaviour as live mycobacteria relates overall to the three ways in which they are expressed in the mycobacterium. Examples of these are PcaA and MmaA2 mutants that express mycolic acids without $\alpha$-mycolate cyclopropanation $[10,11]$, CmaA2 mutants that are unable to effect trans-cyclopropanation in the oxygenated mycolates [12], or MmaA4 and MmaA3 mutants that produce mycolic acids without distal functionality of the oxygenated mycolates $[13,14]$. The significance of secreted free mycolic 
acids as potential role players in the manifestation of tuberculosis was recently noted when Ojha et al. (2008) [15] demonstrated their role in biofilm formation during in vitro growth of M. tuberculosis.

In this review, the focus is on the structure-function relationship of free mycolic acids, in particular their immunoregulatory and cholesteroid nature, as discovered by their isolation and chemical modification, their stereo-controlled chemical synthesis, their immune steering properties and their recognition by monoclonal and polyclonal antibodies.

\section{Structural properties of mycolic acids of Mycobacterium species}

\subsection{Mycolic acid patterns characteristic of mycobacteria}

The initial work on the characterization of mycolic acids from Mycobacterium tuberculosis by Asselineau and Lederer [16], was followed by the assignment of complete overall structures to a number of classes of mycolic acid through the work of, e.g., Etemadi and Lederer and Minnikin and Polgar. Thus in 1966, the first structures of three major classes of mycolic acid, $\alpha$-mycolic acid (2) [17], keto-MA (3) and methoxy-MA (4, 5) were proposed (Fig. 2) [18, 19].

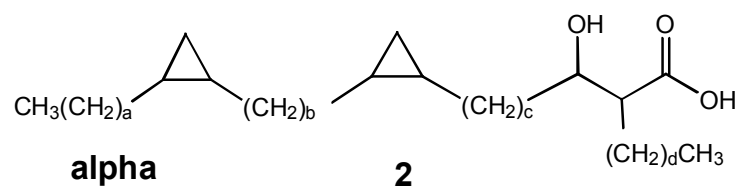<smiles>CCC(C)C(=O)CC1CC1CC(C)C(C)C(C)C</smiles>

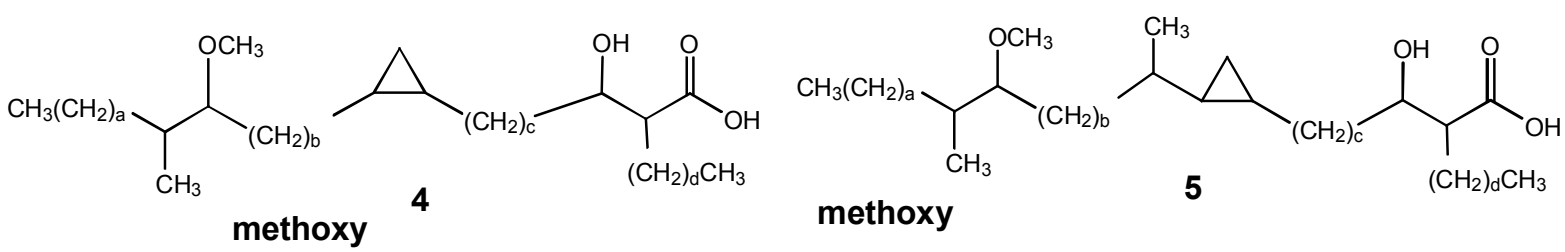<smiles>CCNC(C)OC(C)=O</smiles>

wax ester<smiles>CC1CC1CC(O)C(C)C(=O)O</smiles>

6

$$
\left(\mathrm{CH}_{2}\right)_{\mathrm{d}} \mathrm{CH}_{3}
$$

Figure 2. Major types of mycolic acid from M. tuberculosis complex (2) - (5) [17-19] and a related wax ester from Mycobacterium paratuberculosis

The stereochemistry of the $\beta$-hydroxy-acid fragment was assigned as $R, R[20,21]$. In addition, it was shown that the cyclopropane units present in $\alpha$-MA, methoxy-MA or keto-MA could either have cis-stereochemistry as in (4) or $\alpha$-methyl-trans-cyclopropane stereochemistry as in (5), with the methyl substituent on the distal side of the cyclopropane from the hydroxy-acid $[22,23]$. 
The detailed patterns of the mycolic acid components of a number of strains of M. tuberculosis and some other mycobacteria have been elegantly collected through the work of Watanabe et al. [24, 25]. The total mixture of methyl esters was analysed first by ${ }^{1} \mathrm{H}$ NMR spectroscopy, then separated into $\alpha$-, methoxy and ketomycolates. Each class was further split into those containing no double bonds, one trans-alkene and one cis-alkene using argentation chromatography. The detailed chain lengths could then be determined using mass spectrometry after pyrolysis to fragment the mycolic acid to produce the meromycolate fragment. For the species examined, which also included Mycobacterium bovis, Mycobacterium microti, Mycobacterium kansasii and Mycobacterium avium, the major components of each class contained cis- or trans-cyclopropanes and lacked alkenes; however, minor proportions of unsaturated compounds were also often seen. A number of strains contained tricyclopropanes with chains extended by 6 to 8 carbons. The methoxy-MA and keto-MA from most M.tuberculosis strains had minor components with additional cyclopropane rings; these were major components of the attenuated H37Ra strain which gave a different MA profile to the other Mtb strains. The MAs were categorised according to Fig. 3. In some mycobacteria, such as Mycobacterium paratuberculosis, mycolic acids are accompanied by wax esters (6) (Fig. 2) [29].

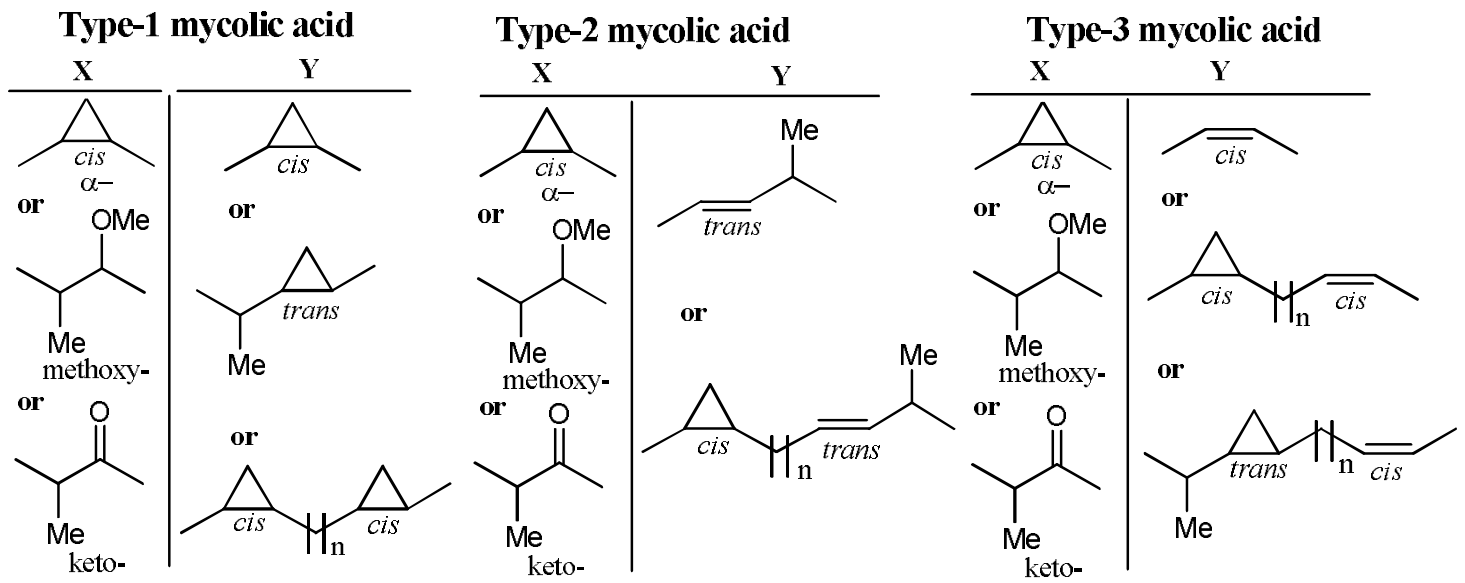

Figure 3. Common categories of mycolic acids [24].

This and earlier work showed very clearly that different mycobacteria contain different complex mixtures of mycolic acids that can provide a fingerprint. Moreover, different strains of M.tuberculosis contained significantly different components. Some selected examples are presented in Table 1 [24]. 
Table 1: The overall balance of mycolic acids in various strains of M. tuberculosis [24].

\begin{tabular}{|l|l|l|l|l|l|}
\hline Strain & Alkenes (\%) & $\begin{array}{l}\text { Stereo- } \\
\text { chemistry } \\
\text { cis/trans }\end{array}$ & $\begin{array}{l}\text { Cyclopropane } \\
(\text { cis:trans) }\end{array}$ & $\alpha:$ methoxy:keto & $\alpha:$ (methoxy+keto) \\
\hline Aoyama B & 6.0 & $\mathrm{c} / \mathrm{t}$ & $1: 0.18$ & $1: 0.74: 0.25$ & $1: 0.99$ \\
\hline MNC1397 & 4.0 & $\mathrm{c} / \mathrm{t}$ & $1: 0.11$ & $1: 0.78: 0.28$ & $1: 1.06$ \\
\hline $\mathrm{O}$ & 5.0 & $\mathrm{c} / \mathrm{t}$ & $1: 0.13$ & $1: 0.49: 0.10$ & $1: 0.59$ \\
\hline $\mathrm{K}$ & 5.1 & $\mathrm{c} / \mathrm{t}$ & $1: 0.13$ & $1: 0.50: 0.13$ & $1: 0.63$ \\
\hline $9829 / 87$ & 9.5 & «t & $1: 0.15$ & $1: 0.63: 0.34$ & $1: 0.97$ \\
\hline $4610 / 91$ & 6.4 & $\mathrm{c} / \mathrm{t}$ & $1: 0.14$ & $1: 0.72: 0.29$ & $1: 1.01$ \\
\hline $2668 / 92$ & 9.6 & $\mathrm{c}>\mathrm{t}$ & $1: 0.14$ & $1: 0.57: 0.40$ & $1: 0.97$ \\
\hline $\begin{array}{l}\text { Canetti } \\
\text { MNC1485 }\end{array}$ & 18.0 & «t & $1: 0.19$ & $1: 0.64: 0.80$ & $1: 1.24$ \\
\hline H37Rv & 10.7 & $\mathrm{c}>\mathrm{t}$ & $1: 0.14$ & $1: 0.54: 0.49$ & $1: 1.03$ \\
\hline H37Ra & 22.2 & $\mathrm{c}$ & $1:<0.01$ & $1: 0.57: 0.45$ & $1: 1.02$ \\
\hline
\end{tabular}

It is clear from this that there are considerable differences in each of the characteristics reported.

However, it must be noted that the strains were obtained from a range of different sources, cultured in somewhat different ways and therefore that the proportions may reflect, or certainly incorporate, factors other than simple strain differences. Thus changes in the proportion of methoxy- and ketoMA had already been reported during cultivation of Mycobacterium microti [26]. In a second landmark paper, Watanabe et al. identified and collated the positions of the functional groups in the meromycolate fragments of the MA, revealing the full complexity of the mixtures present and again showing considerable difference between H37Ra and other M.tuberculosis strains [25].

Table 2 lists the major components of the series of homologues identified for M.tuberculosis that contain two functionalities $\mathrm{X}$ and $\mathrm{Y}$ in the chain. Given that there are also homologous series of compounds containing three functionalities, the overall complexity of the MA mixture is clear. 
Table 2: Chain lengths and functional groups of the major mycolic acids of M. tuberculosis containing two functionalities $\mathrm{X}$ and $\mathrm{Y}[25]$.

\begin{tabular}{|c|c|c|}
\hline $\mathrm{X}$ & $\mathrm{Y}$ & Major a,b,c,d \\
\hline cis-cyclopropane & cis-cyclopropane & $19-14-11(13)-23$ \\
\hline cis-cyclopropane & $\alpha$-methyl-trans-alkene & $19-13-17-23$ \\
\hline cis-alkene & cis-cyclopropane & $19-14-13(11)-23$ \\
\hline $\mathrm{CH}\left(\mathrm{CH}_{3}\right) \mathrm{CH}\left(\mathrm{OCH}_{3}\right)$ & cis-cyclopropane & $\begin{array}{l}17-16-17-23 \\
(15-14-19-23 \text { in H37Ra) }\end{array}$ \\
\hline $\mathrm{CH}\left(\mathrm{CH}_{3}\right) \mathrm{CH}\left(\mathrm{OCH}_{3}\right)$ & $\begin{array}{l}\alpha \text {-methyl-trans- } \\
\text { cyclopropane }\end{array}$ & $\begin{array}{l}17-16-18-23 \\
(17-16-22(20)-23 \text { in Canetti) }\end{array}$ \\
\hline $\mathrm{CH}\left(\mathrm{CH}_{3}\right) \mathrm{CH}\left(\mathrm{OCH}_{3}\right)$ & $\alpha$-methyl-trans-alkene & $\begin{array}{l}17-19-13-23 \\
(17-19-15-23 \text { in Canetti) }\end{array}$ \\
\hline $\mathrm{CH}\left(\mathrm{CH}_{3}\right) \mathrm{CO}$ & cis-cyclopropane & $\begin{array}{l}17,18,15,23 \\
(15-16-19-23 \text { in } \mathrm{H} 37 \mathrm{Ra})\end{array}$ \\
\hline $\mathrm{CH}\left(\mathrm{CH}_{3}\right) \mathrm{CO}$ & $\begin{array}{l}\alpha \text {-methyl-trans- } \\
\text { cyclopropane }\end{array}$ & $17-18-16-23$ \\
\hline $\mathrm{CH}\left(\mathrm{CH}_{3}\right) \mathrm{CO}$ & $\alpha$-methyl-trans-alkene & $\begin{array}{l}17-19-15(13)-23 \\
(17-17-17-23 \text { in Canetti) }\end{array}$ \\
\hline $\mathrm{CH}\left(\mathrm{CH}_{3}\right) \mathrm{CO}$ & cis-alkene & $17-18-15-23$ \\
\hline
\end{tabular}

The structures in Table 2 represent the major components of a series of homologues in each case. The orientations of the substituents relative to the hydroxy-acid part are as shown in Fig. 3. In addition there are homologous series of mycolic acids containing three functionalities in the chain. The direct analysis of in-tact mycolic acids by MALDI mass spectrometry was first reported by Laval et.al., who were able to detect less than 10 pmol [27]. For M.tuberculosis H37Rv, the typical patterns of groups of $\alpha$-mycolates at $m / z$ peaks of $1146,1174,1202$, and 1230 are seen to overlap 
those of methoxy-MA at 1262, 1290, 1318 and 1346 and keto-MA at 1246, 1274, 1288, 1302, 1316 and 1330. Interestingly, the chain lengths of the MA correlated with the growth rate of the bacterium but also with the strain; thus a comparison of the MA from a wild-type strain of M.tuberculosis and an isogenic mutant with an inactive hma gene showed that the latter produced almost entirely $\alpha-M A$ and no keto-MA of methoxy-MA. The homologous series of $\alpha$-MA seen in the wild strain was accompanied by a second series differing by one $\mathrm{CH}_{2}$-unit and the mass range extended from 1118 to 1258 . MALDI-MS has also been used to provide a detailed analysis of the MA components of the cell wall of M.bovis BCG Tokyo 172 [28].

The mycolic acids of Mycobacterium paratuberculosis are interesting because they contain no methoxy-MA but instead 'wax esters' (6) apparently derived by a Baeyer-Villiger type oxidation of keto-mycolates (Fig. 2) [29].

The major MAs of Mycobacterium smegmatis are a homologous, alpha'- series containing just a cis-alkene in the mero-chain [30-32]. In addition there are two series, one containing two cisalkenes, the other an $\alpha$-methyl-trans-alkene in the proximal position and a cis-alkene at the distal position [33]. Similar series of compounds containing four or five cis-alkenes have been reported for Mycobacterium thamnopheos [34].

Three types of MA have been observed in Mycobacterium aurum. The first is di-unsaturated. The second series are keto-MA but the proximal group is either a cis- or an $\alpha$-methyl-trans-alkene. The third series are wax ester mycolates (having an ester at the distal position) and again either a cis- or an $\alpha$-methyl-trans-alkene at the proximal position [35]. The di-unsaturated MA appears not to be biosynthetically directly related, but the wax ester mycolates appear to be derived from the ketoMA by a biochemical Baeyer-Villiger type process [36].

Epoxy-mycolic acids were isolated from Mycobacterium fortuitum [37], M.smegmatis [38] and a number of other species, while a novel $\omega-1$ methoxy-MA has been reported in Mycobacterium porcinum and a number of other bacteria [39].

Although the MA of mycobacteria have many things in common, as seen above there are also characteristic differences both in the classes of functional group present and in the balance of different chain lengths. The characteristic MA patterns of a large number of mycobacteria were collated using TLC and GC-MS of the meromycolates produced by thermal fragmentation [40, 41]. Although much of the work characterising MA has been carried out by mass spectrometry or GC-MS of meromycolates, HPLC has also been used to provide distinctive profiles of MA. A homologous series of $\alpha$-mycolates from Mtb H37Ra was purified by HPLC under reverse phase conditions and each component characterised by MS, leading to the identification of 10 components with a range of chain lengths [42]. This has been extended to establish characteristic 
HPLC patterns that can be used to distinguish a range of mycobacteria [43, 44]. For example, the MA of M.bovis BCG can be distinguished from those of M.tuberculosis and M. bovis [45]. It can also be used to suggest the phylogenetic position of newly isolated mycobacteria [46]. By coupling HPLC to electrospray ionization quadrupole TOF-MS it is possible to provide both qualitative and semi-quantitative analysis of mycolic acids. In this way the $\alpha$-MA fraction from M.bovis BCG conditions was shown to accumulate during entry to dormancy induced by oxygen deprivation, while the keto-MA fraction was almost entirely eliminated [47].

\subsection{Trehalose mycolates}

A component of the tubercle bacillus known as 'cord factor' occurs in strains of M.tuberculosis which have the ability to multiply in vivo and shows a delayed toxicity to mice as well as having a definite role in virulence. Initial analysis of the active component was carried out by Noll and Bloch [48]. Mass spectrometry of these components was described in 1967, though no molecular ions could be observed [49]. The components, trehalose dimycolate (TDM) (7), trehalose monomycolate (TMM) (8) and related sugar mycolates (Fig. 4) exert a number of very strong immunological effects and are able to stimulate innate, early adaptive and both humoral and cellular adaptive immunity [50].

The distribution of cell surface glycolipids in M.tuberculosis strains has been examined by two dimensional TLC coupled to FAB-MS of the intact lipid and GC-MS of the fatty acid part. Both TDM and TMM are present in virulent and avirulent strains, whereas some other lipids are only present in virulent strains [51].

Direct molecular mass determination of TMM from a series of mycobacteria was reported in 2005 using MALDI-TOF mass spectrometry [52]. This showed marked differences between the various species. TMM from M.tuberculosis showed a distinctive pattern with abundant odd-carbonnumbered $\mathrm{C}_{75}-\mathrm{C}_{85} \alpha$-mycolates containing monocyclopropanoic or monoenoic molecules as well as dicyclopropanes, odd and even carbon methoxy mycolates $\left(\mathrm{C}_{83}-\mathrm{C}_{94}\right)$ and odd and even keto-MA $\left(\mathrm{C}_{83}-\mathrm{C}_{94}\right)$. Some $24-38$ significant components were identified. The results could be confirmed by hydrolysis and analysis of the derived MA methyl esters. Significant differences were also seen between the TMM components of M.tuberculosis H37Rv and Aoyama B, while the TMM from M.bovis BCG Connaught lacked methoxy-MA almost completely. The component MAs from M.tuberculosis TMM and TDM were very similar, though not identical. In particular, the relative size of MALDI peaks was very significantly different, though the MA pattern from $M$. tuberculosis TDM was very similar to that of membrane bound MA [52]. 
The analysis of intact TDM is rather more complicated than that of TMM because of the possible combinations of two different MA that are possible. Nonetheless, advised by an analysis of the MALDI patterns for the MA methyl esters derived by hydrolysis of the TDM, it has been possible to analyse these complex mixtures. A marked difference was seen between different mycobacterial species. Thus TDM from M. tuberculosis (HR37Rv and Aoyama B) showed over 60 molecular ions while that from M. bovis BCG Tokyo 172 showed over 35. In contrast, M. bovis BCG Connaught showed less than 35 molecular ions, because of the complete absence of methoxy-MA. Since the physico-chemical properties and antigenic structure of the TDM affect the host immune responses, the detailed profiling of intact TDM represents a significant advance [53, 54]. TDM and TMM prepared from single synthetic alpha- and methoxy-mycolic acids have been reported [55].

\subsection{Other mycolate esters}

Among the mycobacterial lipids presented on CD1b (see 3.1.1) are free mycolic acids and glucose monomycolate (GMM) [56]. T-cell recognition is highly specific for the precise structure of natural GMM including the glucose, the linkage of the glucose to the mycolate and the $R, R$ stereochemistry of the hydroxyl acid part of the mycolate [57]. Upon infection mycobacteria begin to produce GMM which provides a good indicator of local invasion. The GMM is produced more at $30{ }^{\circ} \mathrm{C}$ than $37{ }^{\circ} \mathrm{C}$ and is recognised by a GMM-specific, $\mathrm{CD} 1$-restricted T-cell line isolated from human skin. MALDI-TOF analysis of GMM derived from M. smegmatis shows a majority of peaks corresponding to $\alpha$-mycolates $\left(\mathrm{C}_{74}, \mathrm{C}_{76}, \mathrm{C}_{77}, \mathrm{C}_{78}, \mathrm{C}_{79}, \mathrm{C}_{80}\right)$ [58].

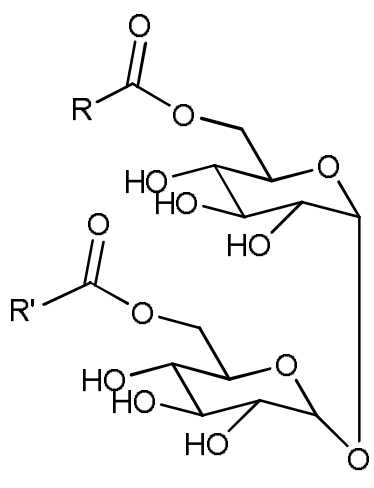

7<smiles>[R]C(=O)OCC1OC(CO)C2OC(CO)C(O)C(O)C(O)C(O1)C(O)C(O)C2O</smiles>

8<smiles>[R]C(=O)OC1OCC(O)CC1OCC(O)(O)CO</smiles>

9

Figure 4. Generic structures of trehalose dimycolate (TDM) (7), monomycolate (TMM) (8) and 5-mycolyl-a-arabinofuranyosyl $\left(1 \rightarrow 1\right.$ ')-glycerol $(9)\left(\mathrm{RCOOH}, \mathrm{R}^{\prime} \mathrm{COOH}=\right.$ mycolic acid) 
A novel 5-mycolyl- $\alpha$-arabinofuranyosyl $\left(1 \rightarrow 1^{\prime}\right)$-glycerol (9, Fig. 4) has been isolated from the Mycobacterium avium-Mycobacterium intracellulare complex [59]. Even a very simple monomycolylglycerol (MMG) has the ability to stimulate human dendritic cells, while a model based on just a $\mathrm{C}_{32}$ chain has similar effects [60].

\subsection{The stereochemistry of mycolic acids}

In all the cases where it has been established, the $\beta$-hydroxy-acid fragment of mycolic acids has been shown to be of $R, R$-absolute stereochemistry. The $\mathrm{CH}_{2}(\mathrm{CHMe})(\mathrm{CHOMe}) \mathrm{CH}_{2}$ fragment of methoxy-MA has also been shown to be of $S, S$-absolute stereochemistry. It has been proposed that the biosynthesis of various functionalities in MA proceeds through a common intermediate, a cation produced by alkylation of a cis-alkene. This can then either lose a proton from the methyl group to produce a cis-cyclopropane, from an adjacent methylene group to produce a methylsubstituted trans-alkene or be trapped as an alcohol. The latter can then in turn be converted into methoxy-and keto-MA (Fig. 5 [61].

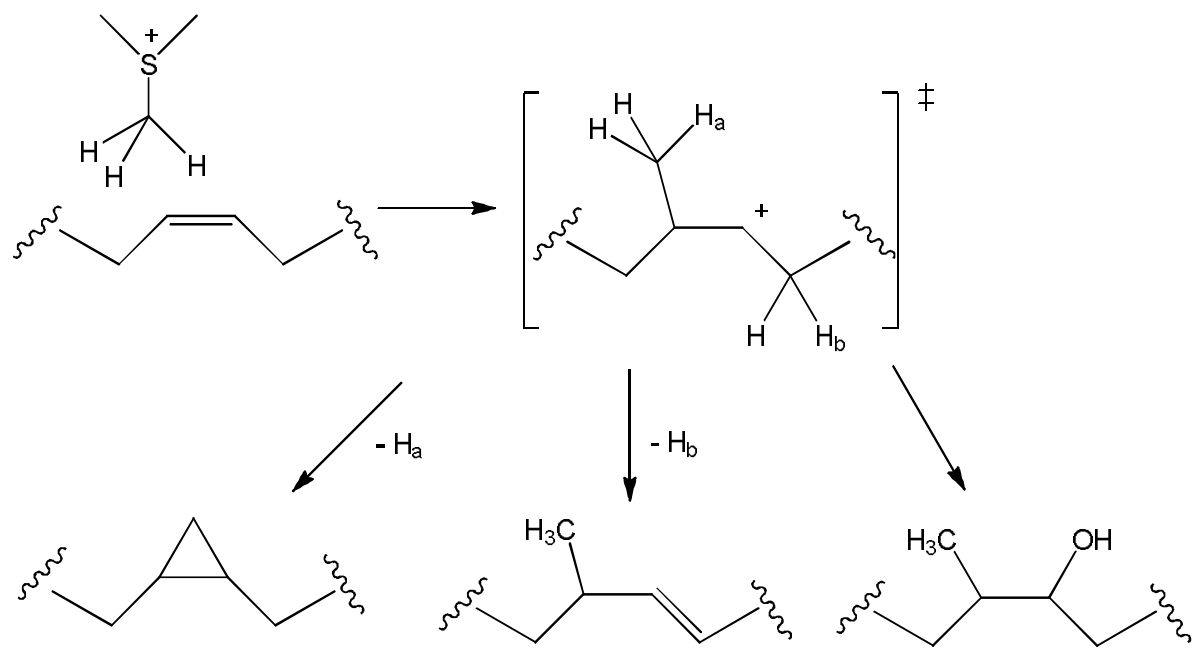

Figure 5. A common pathway to methoxy, keto and cyclopropane mycolic acids [61].

In support of some elements of this mechanism, the fast growing M.smegmatis normally produces oxygenated mycolic acids with an epoxy group. However, if a set of four genes from M.bovis BCG coding for methyl transferases is transferred into M.smegmatis, this produces keto-mycolic acid together with a hydroxy-mycolic acid, both of which are cyclopropanated. There is a perfect match between the structures of the keto- and hydroxy-MA [62]. More detailed analysis showed that both M.bovis BCG and M.tuberculosis also produce small amounts of hydroxy-MA and again 
there appears to be a direct relationship between hydroxy-MA and keto-MA [63]. Although cyclopropanated MAs were previously thought not to abound in M.smegmatis, it was recently shown that the genes to effect this are present in the genome and can be induced for expression at low temperature growth conditions [65].

\subsection{Synthetic mycolic acids}

The discussion above emphasises the singular complexity of natural mixtures of mycolic acids and of derived sugar esters. It further highlights the difficulty in isolating a single natural molecule and in assigning a complete structure, including its stereochemistry. Moreover, the important role of such compounds in the immune system and their changing nature during the progression of diseases such as tuberculosis very clearly demonstrate their potential in therapy, prosthetics and in the diagnosis of infection. In natural mixtures, such effects may be a reflection of the overall complex mixture, or may in fact be dominated by individual molecules or groups of molecules. The beneficial effects of the natural mixtures may be outweighed by their toxic effects, as in the case of Freund's complete adjuvant. Moreover, the application of such mixtures produced by cells may be limited considerably by the potential for subtle but nonetheless significant changes in their detailed make up. For all these reasons, it is important to be able to prepare and evaluate single molecules identical to the various components of natural mixtures.<smiles>CCC[C@@H]1C[C@@H]1C[C@@H]1C[C@@H]1C[C@H](O)[C@H](CC)C(=O)OC</smiles>

17<smiles>CC[C@H](O)C(=O)CC[C@@H]1C[C@H]1C[C@H](O)[C@H](O)C(=O)O</smiles><smiles>CC[C@H](C)C(=O)CC[C@@H](C)[C@H]1C[C@H]1CC[C@H](O)[C@@H](CC)C(=O)OC</smiles>

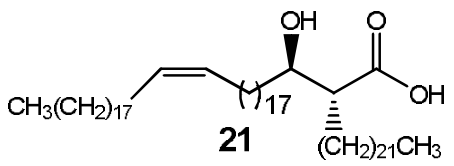

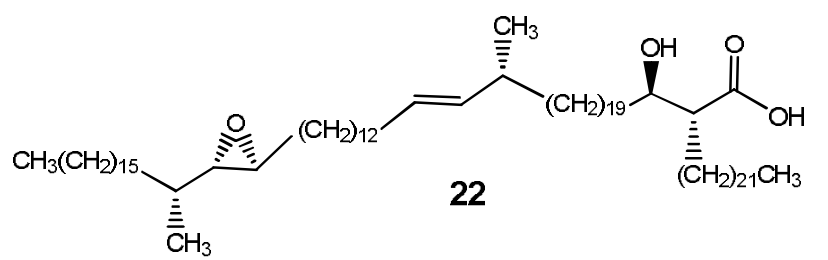

Figure 6. Examples of synthetic mycolic acids. 
The first synthetic mycolic acid reported was the protected $\alpha$-mycolic acid (17, Fig. 6) [64]. Since that time, all four possible diastereomers of this di-cis-cyclopropane-MA have been synthesised. Based on the model in Fig. 5 and assuming that both proximal and distal cyclopropanes are introduced with the same geometry, isomer $\mathbf{1 7}$ has the natural stereochemistry.

In the same way, three stereoisomers of the major methoxy-MA of M.tuberculosis, including (18) [66] as well as keto-mycolic acids containing both cis- and trans-cyclopropanes (19) and (20) have been reported (Fig. 6) [67, 68]. In addition, single synthetic MAs containing just cis-alkenes (21) [69], trans-alkenes [70] and epoxy-MA (22) [71] have been reported (Fig. 6).

\subsection{Does structure matter?}

There are a number of observations suggesting that the detailed structures of natural mycolic acids and their sugar esters are important:

- In at least Mycobacterium phlei and M. smegmatis, the balance of different classes of MA changes with the temperature at which the organism is grown, possibly to manipulate the membrane properties $[65,72]$.

- Cells of mycobacteria grown at higher temperature contain increased levels of trans-MA and have a higher melting temperature; moreover, they allow a less rapid influx of some drugs [73].

- The proportion of trans-substituted cyclopropane at the proximal position of MA is important in determining the fluidity of the cell wall. By over-expressing MMAS-1, an enzyme in the gene cluster responsible for biosynthesis of methoxy-MA, an increase was seen in the production of both trans-alkene and trans-cyclopropane mycolates, and in the proportion of keto-MA to methoxy-MA. This was accompanied by a substantially decreased growth rate at elevated temperature and an increased permeability of the cell wall [74].

- Cyclopropane modification of M. tuberculosis cell envelope TDM is critical for bacterial growth during the first week of infection in mice. TDM isolated from a mutant deficient in the cyclopropane synthase PcaA is hypoinflammatory for macrophages and induces less severe granulatomous inflammation, showing that the fine structure of the mycolates in these lipids directly affects pathogenesis and temporal control of the host immune activation through cyclopropane modification [75].

- TDM isolated from a mutant $(\triangle c m a A 2)$ that lacks the capacity for trans-cyclopropanation is five times more potent in stimulating macrophages than TDM isolated from wild-type $M$. tuberculosis. This establishes cmaA2 dependent trans-cyclopropanation of MA as an activity to suppress $M$. tuberculosis induced inflammation and virulence. Moreover, the 
stereochemistry of the cyclopropane changes the interaction with the host cell to influence host innate immune responses both positively and negatively [76, 77].

- One of the strategies used by M. tuberculosis to avoid elimination by the host is the selective repression of macrophage IL-12p40 production. The mmaA4 gene which encodes a methyl transferase required for the introduction of oxygen substituents at the distal position of MA is a key locus in this suppression. This suggests that M. tuberculosis has evolved mmaA4derived mycolic acids into TDM to manipulate IL-12-mediated immunity and virulence [9].

\section{Structure-function relationship of free mycolic acids}

\subsection{Immunoregulatory properties of natural and synthetic mycolic acids}

The different functions exerted by mycolic acids from M. tuberculosis and their synthetic counterparts along with their potential consequences for the pathogenesis of tuberculosis are schematically illustrated in Fig. 7.

\subsubsection{MA and CD1 restricted $T$ cells}

An important aspect of immunoregulation is the presentation of processed antigen on antigen presenting cells (APC) to responder T cells. Protein antigens are processed and peptides presented on major histocompatibility complex (MHC) proteins. Responder $\mathrm{T}$ cells are divided broadly into CD4 and CD8 expressing cells, of which CD4 T cells are generally known as helper $\mathrm{T}$ cells with main function to facilitate cellular and humoral (antibody, cytokine) immunity, while CD8 $\mathrm{T}$ cells are effector cells that kill target cells, but also influence the control of immunity. $\mathrm{T}$ cells responding to peptides presented on $\mathrm{MHC}$ are 'MHC restricted'. CD4 T cells are MHC-II restricted, with MHC-II membrane proteins, typical of APCs, generally presenting peptides from exogenously captured antigen, while CD8 T cells are MHC-I restricted, with MHC-I membrane proteins, typically present on all nucleated cells, generally presenting peptides from endogenously biosynthetized antigen, such as virus or tumor-associated proteins.

A particular role for mycobacterial mycolic acids in immune regulation was reported in 1994, when Beckman et al. [78] showed for the first time that MA presentation on CD1, in particular CD1b of human dendritic cells, stimulated CD4/CD8 double negative T cell lines, representative of a minor population of $\mathrm{T}$ cells in the blood circulation believed to be mainly involved in the regulation of auto-immunity. This was the first indication of the function of the $\mathrm{CD} 1$ family of membrane proteins as lipid antigen presenting molecules on antigen presenting cells. The role of CD1 as a presenter of various lipids to direct innate and adaptive immune responses was recently reviewed by Cohen et al., 2009 [79]: During the folding of 


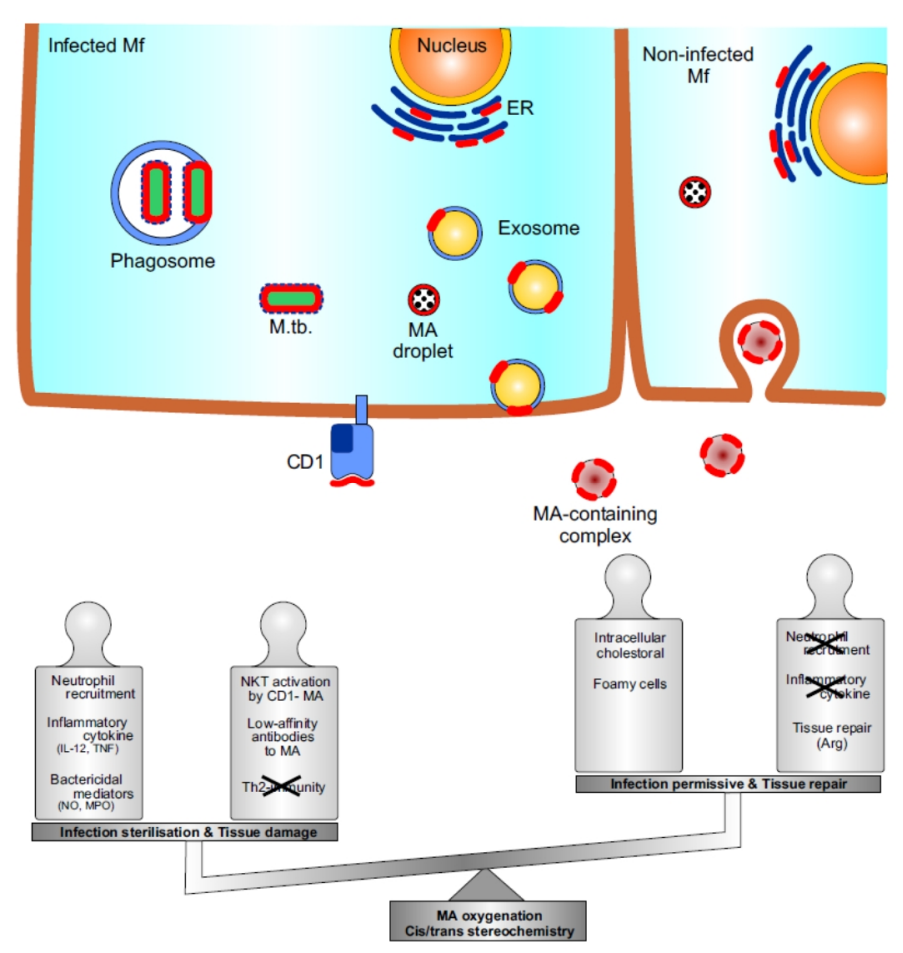

Figure 7. Mycolic acids balance the host immune response to infection.

Top: In infected macrophages, the acidic $\mathrm{pH}$ from the phagosome may promote the dissociation of cell wall-associated structures such as LAM, TDM and others, resulting in an increased exposure of cell wall mycolic acids (red stretch). The highly hydrophobic nature of the exposed mycolic acid moieties may promote spontaneous association with the phagosome membrane, thus bringing the mycolic acids in direct contact with the cytosolic cell compartment. In human macrophages, $M$. tuberculosis bacilli also occur outside of the phagosome in the cytosol of the infected cell. Here, enzymatic processing of TDM by serine esterases may promote the formation of free mycolic acids. Again, the highly hydrophobic nature of the free mycolic acids will promote association with intracellular membranes and/or lead to the formation of mycolic acid-containing lipid droplets. ERassociated mycolic acids may in addition be presented on the surface of the cell by the MHC I mimic, CD1. Through as yet poorly understood mechanisms, the intracellular free mycolic acids trigger signaling pathways leading to the activation and differentiation of the infected macrophage. Endocytosis of excreted mycolic acid-containing complexes by non-infected neighboring macrophages may trigger through similar pathways the activation and differentiation of the cell, hereby promoting a bystander effect. Bottom: The functions elicited by free mycolic acids are divergent and may support increased anti-bacterial defenses or increased permissiveness to infection along with tissue repair responses. Increasing evidence supports the notion that the level and type of mycolic acid oxygenation as well as the cis- and trans-cyclopropane stereochemistry are crucial in balancing these opposite macrophage functions.

Arg: arginase; ER: endoplasmic reticulum; M.tb: Mycobacterium tuberculosis; MA: mycolic acids; Mf: macrophage; MHC: major histocompatibility complex; MPO: myeloperoxidase; NKT: natural killer T-cell; NO: nitrogen oxide radical.

nascent $\mathrm{CD} 1$ in the endoplasmic reticulum, microsomal triglyceride transfer protein (MTP) appears to facilitate the loading of CD1 with self-lipids, that are later replaced by exogenous microbial lipids during endosomal trafficking. Each CD1 molecule may accommodate 
different types of lipids and each CD1 molecule has hydrophobic pockets determining preferential binding to different lipids. The various members of CD1(a-e) are loaded early or late in the endosomal/phagosomal maturation pathway. Thus, glucose monomycolate (GMM) with short lipid tail length MAs (32C) is loaded on CD1b early, while GMMs with longer lipid tail length MAs (80C) are loaded late on CD1b in endosomal maturation. CD1e appeared not to be involved directly in antigen presentation as a membrane anchored protein. Rather, it was observed to be involved with the processing of lipid antigens in lysosomes, much like the lipid transfer proteins do [80]. Some of the more complex exogenous lipids require endosomal processing, while others are loaded and presented without processing. There is no published evidence that lipases are involved in lipid antigen processing for CD1 loading. In mice, it was shown for some glycolipid antigens that terminal sugars were removed by specific glycosidases before CD1d loading was permitted [81], analogous to the system for glycopeptide antigen processing before presentation to $\mathrm{T}$ cells. Acidification of late stage endosomes is often required to enable loading of $\mathrm{CD} 1$, while transfer of the water insoluble larger lipids, including the mycobacterial mycolic acids, from endosomal membranes to CD1 is facilitated by specific lipid transfer proteins of the phagosomal saposin family, selectively active in early or late stage lipid processing aiming towards presentation of the lipids to T cells or NK T cells. Soluble CD1e was first shown to facilitate the removal of sugars from the larger glycolipids before their presentation on CD1b [82]. Later, Facciotti et al. [80] demonstrated that this type of facilitation by soluble CD1e happens mainly by its role as a selective lipid transfer protein that can enable both the loading and unloading of CD1 molecules of the CD1b, CD1c and CD1d types.

CD1-restricted $\mathrm{T}$ cells appear to respond to $\mathrm{CD} 1$ presented antigens that appear on the professional antigen presenting cells, i.e. dendritic cells and B cells. Certain lipid antigens, mainly those with long hydrophobic tails like MA, are presented by the so-called Type I CD1, comprising the human CD1a, CD1b and CD1c. The Type II CD1 presents preferably glycosylated lipids with shorter hydrophobic tails and comprises CD1d in humans. In rodents, only Type II CD1 is found on antigen presenting cells.

Type I CD1 presents lipid antigens to $\mathrm{T}$ cells, which respond by polyclonal activation, suggesting a relatively wide range of specificities for antigen binding [83] In contrast, Type II CD1 molecules present lipids to Natural Killer T (NKT) cells with structurally more conserved $\mathrm{T}$ cell antigen receptors [84]

In the early days following the discovery that human dendritic cells presented mycobacterial MA to $\mathrm{T}$ cell lines, it was believed that only $\mathrm{CD} 4 / \mathrm{CD} 8$ double negative and $\mathrm{CD} 8$ positive $\mathrm{T}$ 
cells were responsive to the presented MA [85]. Indeed, it was shown that both these T cell types secreted IFN $\gamma$ that can protect against M. tuberculosis infection [86] and could induce apoptosis of infected macrophages [87]. Later, work on MA stimulation of human T cells by Goodrum et al. [88] used whole peripheral blood monocytes from freshly donated normal human blood, with which it was shown that CD4 single positive T cells proliferated strongest, followed by double negative $\mathrm{T}$ cells, while very few $\mathrm{CD} 8$ single positive $\mathrm{T}$ cells responded to MA stimulation. This was corroborated by Montamat-Sicotte et al. in 2011 [89], who reported that CD4 single positive cells were the main responders to MA stimulation in the peripheral blood monocytes of human TB patients. In these patients, CD8 single positive cells were also stimulated strongly, while only a small response to MA from double negative T cells were recorded.

The exact role of MA responsive CD1 restricted $\mathrm{T}$ cells in tuberculosis remains unresolved. Sieling et al. [90] reported that CD4/CD8 double negative T cells from auto-immune systemic lupus erythematosus (SLE) patients induced antibody isotype switching from IgM to $\operatorname{IgG}$ in a CD1c restricted manner characterised by Interleukin 4 secretion of the CD1c restricted SLE double negative $\mathrm{T}$ cells. $\mathrm{CD} 1 \mathrm{c}$ restricted double negative $\mathrm{T}$ cells from healthy donors did not secrete IL4 and did not facilitate antibody isotype switching. In the case of tuberculosis, Montamat-Sicotte et al. [89] reported that MA appears to be a main target for $\mathrm{T}$ cells in tuberculosis. Specific T cells were found to abound at diagnosis, but contracted faster upon treatment of the patients with anti-TB drugs than was the case with TB protein specific $\mathrm{T}$ cells, thereby being more sensitive towards pathogen-burden. Although the MA specific T cells were found to exhibit properties of memory $\mathrm{T}$ cells, including the property of rapid expansion upon antigen reencounter, the vaccine potential of MA awaits better understanding of the role of CD1-restricted, MA responsive T cells in tuberculosis. For instance, the vaccine potential of the human APC CD1b presented sulfoglycolipid, 2-palmitoyl or 2-stearoyl-3hydroxyphthioceranoyl-2'-sulfate- $\alpha-\alpha$-D-trehalose (Ac2SGL) from M. tuberculosis was demonstrated by its ability to stimulate Ac2SGL-specific T cells with concomitant release of interferon $\gamma$, recognition of $M$. tuberculosis-infected cells, and killing of intracellular bacteria. The ability to clone such Ac2SGL-responsive T cells from humans strictly depended on the latter's previous contact with M. tuberculosis, without necessarily manifesting the disease [91]. Thanyani et al. in 2008 [92] associated active TB with biomarker antibodies to MA that may be regarded as auto-immune in that they are associated with a simultaneous increase in anti-cholesterol antibody activity in TB patient sera. How this may relate to the establishment of TB is discussed in more detail below. 


\subsubsection{MA and macrophages}

Specialized immune cells, especially macrophages, mast cells and dendritic cells express a diverse repertoire of germ-line encoded pattern recognition receptors (PRRs) that are pivotal in the early detection of infectious pathogens and the subsequent activation of innate immune defences. This enables the development of adaptive immune defences by steering the differentiation of naïve $\mathrm{CD}^{+}{ }^{+} \mathrm{T}$-lymphocytes towards helper $\mathrm{T}$-cell (Th) subsets supporting cellular $\left(\mathrm{Th}_{1}, \mathrm{Th}_{17}\right)$ or humoral $\left(\mathrm{Th}_{2}, \mathrm{Th}_{3}\right)$ immune defences. In sharp contrast to the highly specific receptors for antigen expressed by B- and T-lymphocytes, PRRs exhibit low specificity and distinguish infectious non-self from non-infectious self on the basis of pathogen-associated molecular patterns (PAMPs). M. tuberculosis bacilli express several well characterized PAMPs (reviewed in [93, 94, 95]). Among others, the cell wall skeleton fraction of $M$. tuberculosis, a complex of mycolic acids bound to peptidoglycan through arabinogalactan, mediates inflammatory activation of macrophages and dendritic cells through TLR2 and TLR4 $[96,97]$. The peptidoglycan domain rather than the arabinogalactan and mycolate moieties of the cell wall skeleton was later identified as responsible for this TLR2 and TLR4 dependent activation of innate immune cells [98]. Other M. tuberculosis cell wall structures representing PAMPs and exerting activation and/or modulation of host immune responses include lipoglycans such as lipoarabinomannan (LAM) [99, 100] and trehalose dimycolate (TDM) [101, 102], the $19 \mathrm{kDa}$ lipoprotein stimulating TLR2 [103, 104], sulfolipids [105], and the cell wall-associated lipid phthiocerol dimycocerosate [106, 107].

The pronounced impact on overall mycobacterial fitness of genetic approaches to describe the biological roles of mycolic acid lipids has as a consequence that it is not possible to segregate a role for free mycolic acids in manipulating host immune responses to infection. For that reason, Korf et al. addressed the relation to host immunity of $M$. tuberculosis mycolates by examining the interaction with macrophages of isolated mycolic acids. To overcome the poor solubility in water of the highly hydrophobic, wax-like lipids, liposomes were used as vehicles for subsequent administration into mice [108]. Following phagocytosis by murine macrophages, mycolic acids were found to colocalize with acidic phagosomes. This absence of interference with phagosome maturation and acidification is in contrast with the intact mycobacterium that generally inhibits maturation and acidification of phagocytic compartments as a strategy to promote its own survival $[109,110]$. However, administration of mycolic acids to the airways mimicked other features of $M$. tuberculosis infection. Thus similar to the recruitment of neutrophils, monocytes and lymphocytes observed in tuberculosis patients, mycolic acids elicited an acute neutrophilic airway inflammation which was accompanied by a moderate and chronic IL-12 production [108]. Macrophages showed only a mild inflammatory activation but exhibited a strongly increased reactivity when 
challenged with suboptimal concentrations of heat-killed M. tuberculosis. Among others, the production of the antimicrobial enzyme, myeloperoxidase, and the inflammatory cytokine, IFN- $\gamma$ were strongly induced under these conditions. Myeloperoxidase is a heme enzyme that generates reactive oxidants and has been implicated in mycobacterial killing [111]. IFN- $\gamma$, along with IL-12, has been shown to be a pivotal cytokine in the control of M. tuberculosis infection in mice and humans. These observations identify mycolic acids as a (mildly) proinflammatory PAMP from M. tuberculosis that in addition primes macrophages for a future infection by increasing the capacity of the cells to raise antimicrobial defenses. Strikingly, also Fenhals and colleagues [112] observed expression of IFN- $\gamma$ in macrophages in human tuberculous granulomas. Isolated mycolic acids therefore appear to elicit innate immune responses characteristically generated during $M$. tuberculosis infection.

T-lymphocyte responses strongly biased towards IFN- $\gamma$-producing $\mathrm{Th}_{1}$ lymphocytes are a hallmark of tuberculosis in patients and mouse models. Chronically increased levels of the instructive cytokines IL-12 and IFN- $\gamma$ in the infected lung are crucial in promoting this $\mathrm{Th}_{1}$ bias of the pulmonary immune response. In contrast, immune responses to nonmicrobial airborne environmental antigens in allergic subjects are strongly biased towards $\mathrm{Th}_{2}$ lymphocytes, instructed by a predominance of the cytokine IL-4. Asthma, a chronic inflammatory disorder of the airways, is driven by a $\mathrm{Th}_{2}$ cell response to inhaled allergen and presents, as distinctive pathology, a bronchoalveolar inflammatory infiltrate consisting of eosinophils, basophils, and mast cells $[113,114]$ rather than neutrophils and monocytes/macrophages observed in $\mathrm{Th}_{1}$-driven inflammatory responses. Interestingly, population studies showed an inverse correlation between the clinical prevalence of asthma and the incidence of microbial infections such as tuberculosis [115]. The failure of PAMPs or bacterial infections to trigger $\mathrm{Th}_{2}$ cell responses combined with a mutual antagonism between $\mathrm{Th}_{1}$ and $T \mathrm{~h}_{2}$ responses is believed to be at the centre of the inverse relationship between asthma and tuberculosis incidence. Strikingly, a similar antagonism was reported by Korf and colleagues $[109+7]$ when applying mycolic acids, administered by intratracheal instillation, in a mouse model of asthma. A single treatment with M. tuberculosis mycolic acids not only prevented the onset of inhaled allergen-induced eosinophilic airway inflammation but also promoted unresponsiveness to a secondary set of allergen exposures, indicating the occurrence of a $\mathrm{Th}_{2}$ tolerizing condition in mycolic acid-treated lungs. The authors further showed that the development of this tolerant condition depended on IFN- $\gamma$ and could be mimicked by adoptive transfer of mycolic acid treated macrophages [116]. Extrapolated to the human condition, these observations indicate that mycolic acids may actively contribute towards preventing the development of a deleterious, non-protective $\mathrm{Th}_{2}$-lymphocyte host response and support the development of protective $\mathrm{Th}_{1}$-driven cellular immunity. The next 
question is then how the structure of mycolic acids relates to their immunoprotective properties and whether such knowledge can be exploited for the design of vaccine adjuvants to steer immunity towards a beneficial response protective against a variety of infectious diseases.

Vander Beken and colleagues [117] recently addressed this issue by studying the inflammatory properties of chemically homogenous mycolic acids differing in oxygenation class and proximal cyclopropane stereochemical configuration. Using single synthetic mycolic acid isomers, the authors confirmed that the presence and type of an oxygenated distal group in the meromycolate moiety is the main determinant for at least pulmonary inflammatory potency. Thus, whereas alpha-mycolic acid was found not to cause inflammation, oxygenated methoxy- and keto-mycolic acids with cis-cyclopropane stereochemistry elicited strong to mild inflammatory responses respectively. Strikingly, ketomycolic acid with a trans-cyclopropane in the proximal position, exerted anti-inflammatory activation of alveolar macrophages and counterbalanced cis-methoxy-mycolic acid induced airway inflammation. This fine-tuned relation between (anti-) inflammatory potency, mycolic acid oxygenation and cyclopropane stereochemistry observed with individual mycolic acids may explain some of the apparently contradictory observations made with $M$. tuberculosis mutant strains lacking in specific mycolate classes. Furthermore, a differential innate immune activity of individual mycolic acid isomers may provide a means for M. tuberculosis to finetune host innate immunity in response to different growth conditions, such as reduced levels of aerogenation or entry into dormancy versus reactivation; conditions that have been shown before to be accompanied by changes in mycolic acid composition $[47,118,119]$.

\subsubsection{Free mycolic acids in $\mathbf{T B}$}

The bioavailability of free mycolic acids during natural infection has been a matter of debate for a long time. Recent new insights indicate that free mycolic acids may become available during infection to exert innate immune activation. Thus Ojha and colleagues [15] reported the formation, under specific growth conditions, of biofilms in cultures of M. tuberculosis. In the biofilms, the M. tuberculosis bacilli were found to be embedded in an extracellular matrix rich in free mycolic acids. Biofilm formation depended on the expression of groEL1 chaperone and its physical association with KasA, a key component of the type II Fatty Acid Synthase involved in mycolic acid synthesis [120]. M. tuberculosis biofilms containing free mycolic acid are not just an artifact from in vitro growth but have also been described in the infected organism. Within primary granulomas in guinea pig lungs microcolonies with features reminiscent of biofilms and containing extracellular mycolic acids have been 
described [121]. These microcolonies were detected within an acellular rim adjacent to the edge of the mineralizing central necrotic core. Free mycolic acids in these biofilms reportedly are derived from cell envelope glycosylated mycolates and are released by a trehalose dimycolate-specific serine esterase [122]. These new findings support the notion that free mycolic acids in tubercle granulomas may actively contribute to the delicate immune balance maintained in granuloma structures by exerting the divergent pro- and anti-inflammatory activities previously reported with isolated mycolic acids [108, 116, 117].

This leaves open the important issue of the contribution or not of mycolic acids in their natural, cell wall-bound form to the innate immune response of the infected macrophage. Most in vivo and in vitro studies of free mycolic acids used liposomes or other carriers as vehicle for the water insoluble mycolic acids. Besides efficiently targeting phagocytic cells such as macrophages, liposomes in addition are rapidly engulfed by the phagocyte where they end up in the endosomal to lysosomal compartment [108]. This predominantly intracellular location of administered free mycolic acids may explain why transmembrane PRRs such as TLR2 and TLR4 reportedly do not contribute to the elicited inflammatory response [108] and suggests the involvement of other PRRs with either an endolysosomal location or present in the cytosol of the cell. In particular, the family of nucleotide-binding domain and leucine rich repeat-containing receptors (NLRs) may be implicated in the macrophage activation observed upon administration of mycolic acids. NLRs have been shown to detect a broad range of intracellular bacteria but also to sense stress signals resulting from infection [123, 124] or, in the case of mycolic acids, possibly from an intracellular abundance of non-self mycolate lipids. Considering the variety of additional M. tuberculosis PAMPs such as TDM, LAM and others and their pronounced inflammatory potency, mycolic acid immunoregulatory activity may in fact be predominant during dormancy. Here cell wall mycolic acids interacting with cytosolic PRRs such as NLRs may enable an enduring inflammatory conditioning of macrophages harbouring (silent) M. tuberculosis bacilli in spite of the absence of extracellular M. tuberculosis PAMPs that are mostly associated with active disease.

\section{The human antibody response to mycolic acids}

The first report of human TB patient antibodies to mycolic acids appeared by Pan et al. in 1999 [125]. By separating the natural mixture of MA into the three main classes by thin layer chromatography, the authors showed that methoxy- and keto-MA were more antigenic than the non-oxygenated alpha-MA. This was confirmed by Beukes et al. in 2010 [126], using various isomers of stereo-controlled chemically synthetic MAs and showing methoxy-MA to be the most antigenic of the three classes in TB patients. Further analysis showed MA antigenicity to be critically dependent on the fine structure 


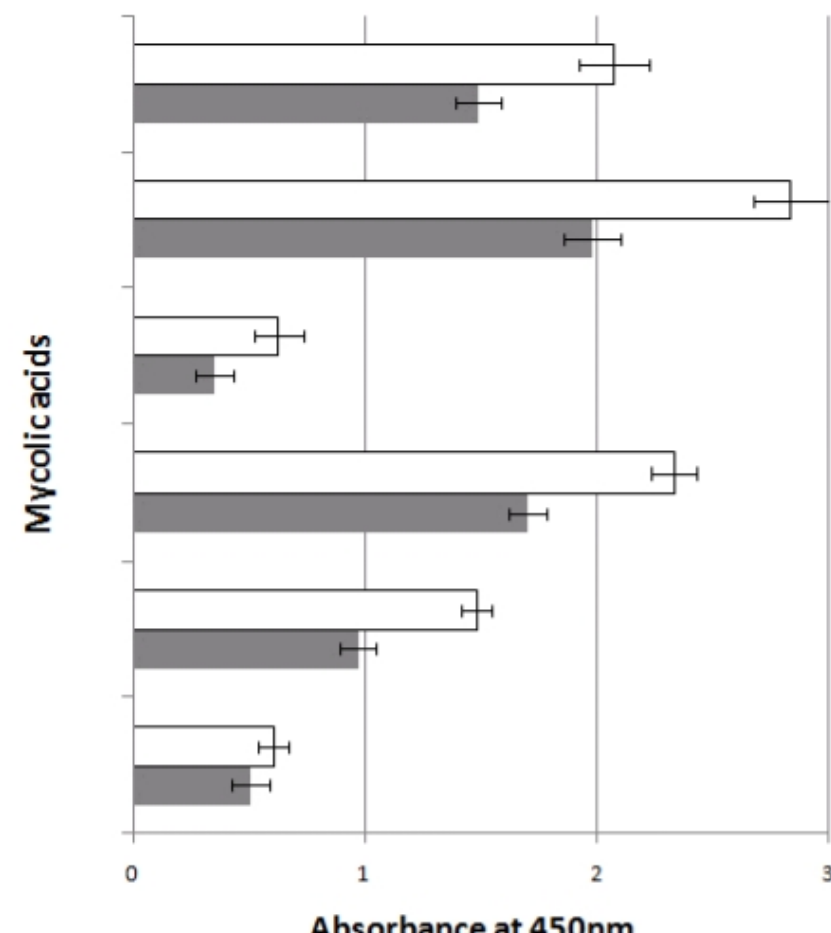

\section{Natural mycolic acid mixture}

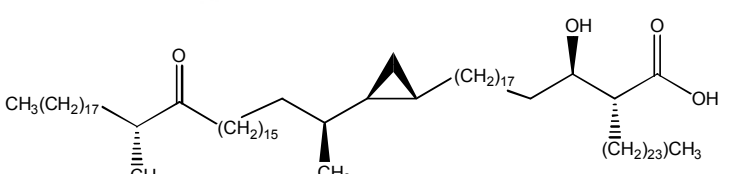<smiles>CC(C)C(O)CC1CC1CC(O)C(C)C(=O)O</smiles>

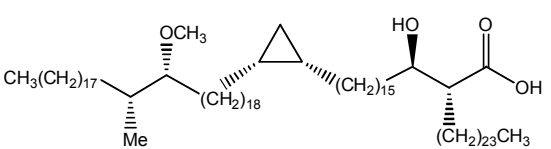

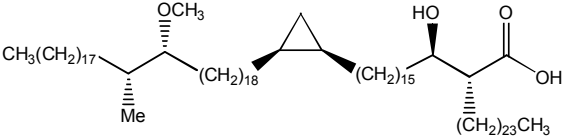<smiles>CC[C@@H](C)[C@H](O)C[C@@H]1C[C@H]1C[C@H](O)[C@H](C)C(=O)O</smiles>

Absorbance at $450 \mathrm{~nm}$

Figure 8. ELISA antibody binding signals of pooled TB positive (blank boxes) and TB negative sera (filled boxes) to natural MA and to five synthetic methoxy MA. The error bars indicate the standard deviation. Natural MA was isolated from M. tuberculosis H37Rv. Adapted from [126].

of the functional groups in the MA merochain. Even the stereochemical configuration of the functional groups was important, as demonstrated in Fig. 8 with various isomers of methoxy-MA. The antibody binding signal to isomer 24 was almost double that of isomer 23, although the only difference between them was the stereochemistry of the proximal cis-cyclopropane. Likewise, the antibody binding signal to isomer 24 was almost three times that of isomer 25 , with the only difference between them being the stereochemistry of the distal methoxy-methyl functional group. Isomer 21, believed to be the closest structural representative of the naturally occurring methoxy-MA of this chain length, was comparatively poorly recognized by TB patient sera. Converting its proximal cis-cyclopropane to a methyl-trans cyclopropane (isomer 26) made it the strongest antigenic isomer of the five that were compared in the figure. Antigenicity was also found to depend critically on the structure of the mycolic motif. In particular, methyl esterification of the carboxylic acid in the motif destroyed antigenicity altogether [126], possibly indicating a critical role of the carboxylic acid in stabilizing an antigenic conformational fold of the MA by hydrogen bonding with the oxygenated distal functional group. 
Currently, TB diagnosis in HIV burdened populations poses one of the most challenging hurdles towards regaining control of the TB epidemic $[127,128]$. The potential for detection of antibodies to MA as biomarker for diagnosis of active TB was emphasized when Schleicher et al. [129] demonstrated in 2002 that the antibody binding signal to MA was not affected by the degree to which the patient was affected by HIV-co-infection. There remained, however, an overlap between the antiMA antibody binding signals between TB patient and control sera that made the ELISA outcome not adequately accurate as a diagnostic indicator. One way to get around this problem was to employ modern antibody detection technology where antibody binding is detected in real time, thereby increasing the sensitivity of the reaction $[92,130]$. These authors also showed that human TB patient anti-MA antibodies included IgG, by demonstrating that a significant part of the anti-MA antibody activity could be purified with Protein A affinity chromatography, known to be insensitive for IgM. The antibody isotypeswitch from IgM to IgG usually involves antigen specific $\mathrm{T}$ cells, hereby distinguishing the anti-MA antibody response as probably a $\mathrm{T}$ cell dependent response, as opposed to $\mathrm{T}$ cell independent responses that are typical of a number of other lipid antigens, in particular glycolipids, and are mainly constrained to IgM responses. Even with the use of biosensor technology to detect antibodies to MA in TB patients, there remained quite a number of false positive outcomes, leaving the question as to what causes some TB negative patients to express antibodies that are reactive to MA. One possibility to determine this would have been to identify individual MA class structures to which antibodies from TB patient sera bound preferentially, as opposed to other more cross-reactive MA structures. The reality that is clear from the data in Fig. 8 is that none of the MA isomers examined showed any significant difference in distinguishing between sera from TB-positive and TB-negative patients. The same applied to isomers of the keto- and alpha-MA classes [126]. Although the antibody binding activity to all the MA-isomers was higher in (pooled) TB positive patient sera than in (pooled) TB negative patient sera, the ratio of binding activity to MA between TB positive and TB negative patient sera remained similar for each MA antigen tested. Whereas this diminishes the prospects of increasing the accuracy of mycolic acid antigen based immunodiagnostic tests for TB by using particular isomers of chemically synthetic mycolic acids, it eases the necessity for defining exactly the class composition of MA antigens that is used to detect the MA-binding antibodies. These MAs may resemble early stage M. tuberculosis when the keto-MA dominates or the late stage when the methoxy-MA dominates [131], with the only difference being slight changes in the magnitude of the signals for both MA antigen sets, with no difference in the ratio of the antibody binding signal from TB positive and TB negative patients.

\section{Cholesteroid nature of mycolic acids}


One lead towards the understanding of the cross-reactivity of MA recognition by TB patient and control sera was the observation that immobilized cholesterol in an ELISA plate could substitute for MA to produce similar antibody binding activity between TB patient and control sera [132]. The authors also showed that cholesterol was attracted to immobilized mycolic acids in an evanescent field biosensor. This could mean that a structural and/or functional relationship exists between MA and cholesterol. The demonstration that Amphotericin B, a cholesterol binding anti-fungal antibiotic, bound equally well to MA as to cholesterol gave credibility to such a notion. Later, Beukes et al. [126] provided more direct proof by providing a recombinant $\mathrm{scFv}$ antibody fragment expressed from a chicken antibody gene library that recognized both MA and cholesterol, indicating that the antibody binding activity to cholesterol could be due to a true functional cross-reactivity with mycolic acids. It has been firmly established that humans generally have variable levels of IgM and IgG anticholesterol antibody activity in the circulation $([133,134]$, thereby providing a possible explanation for the high binding activity to MA observed in TB negative patients. Alving and Wassef [135] proposed in 1999 that endotoxin, found ubiquitously in the environment, could act as a potent adjuvant for the induction of antibodies to cholesterol. The cholesterol source of antibody induction could come from localised sites of infection and inflammation where cellular debris is gathered. In particular, it was shown that HIV-infected individuals express higher amounts of anti-cholesterol antibodies, probably due to the role of cholesterol in the cholesterol-rich lipid raft where HIV is budding from the infected cells, as well as the subsequent insertion of cholesterol into the envelope of the HIV virion [136]. When patients were put on anti-retroviral treatment, the anti-cholesterol antibody titre rapidly declined.

Even if the prevalence of truly cross-reactive anti-MA and anti-cholesterol antibodies could be demonstrated in human sera, cross-reactivity could also be due to a mixture of monospecific anticholesterol and monospecific anti-MA antibodies. Such monospecific scFv specificities were also selected from the chicken antibody gene library by Beukes et al. [126], showing that the recognition of MA by antibody does not necessarily manifest as cross-reactivity to cholesterol. Likewise, scFv antibody fragments to cholesterol did not necessarily cross-react with MA. Whether the antibody cross-reactivity observed in human TB and control patient sera is due to a mixture of monospecific antibodies, a true single antibody cross-reactivity, or both remains to be determined. What seems clear at this stage is that MA and cholesterol may not be recognized as individual haptens, but rather as molecular clusters forming multi-faceted surfaces, of which one or some facets can cross-react, while other facets may be restricted to mono-specific recognition by antibodies to either cholesterol or MA. For this reason the structure of MA recognized by a truly cross-reactive anti-MA/cholesterol antibody could better be referred to as the cholesteroid face (with-oid indicating a particular shape, form or resemblance) of a cluster of MAs constituting an antigenic determinant. Studies of MA monolayers 
indeed confirmed that they were not uniform in terms of surface topography, showing significant variation of film thickness and conformational depencency on the presence of water [137]. In the body, MAs can be expected to be present in the context of a phospholipid complex, such as in a membrane or in a lipoprotein, which further complicates the interpretation of ELISA results where MAs are recognised as precipitates on polystyrene.

Cholesterol is not normally present in prokaryotes, including the mycobacteria. The manipulation of the micro-environmental host cholesterol concentration by M. tuberculosis may be of strategic benefit for pathogenesis. One possible role for the cholesteroid nature of MA in TB pathogenesis may be found in the role that cholesterol plays in phagosomal maturation during mycobacterial infection of the host macrophage. Cholesterol mediates the binding of TACO, an actin binding protein [138], on live mycobacteria-containing phagosomes in order to prevent lysosomal degradation of the mycobacteria [139]. Upon cholesterol depletion of pre-existing phagosomes, the close apposition between the phagosome membrane and the mycobacterial surface is loosened and fusion with lysosomes occurs $[140,141]$, leading to destruction of the pathogen. TACO is retained on the phagosome by cholesterol from the host as well as by the mycobacterial protein, coronin interacting protein (CIP)50, later identified as lipoamide dehydrogenase C (LpdC) [142]. LpdC is the E3 component of the pyruvate dehydrogenase complex. Cholesterol depletion of the phagosome membrane inhibited the TACO - LpdC interaction showing the cholesterol dependence of the association. TACO is responsible for activating the $\mathrm{Ca}^{2+}$ dependent phosphatase calcineurin. This leads to the inhibition of lysosomal delivery $[143,144]$. From the perspective of the property of mycolic acids to attract cholesterol and their demonstrated release from trehalose-mycolates at the mycobacterial cell surface, one can predict that MA in the phagosomal membrane would be able to facilitate cholesterol accumulation to ensure TACO retention at the interface between the phagosomal membrane and the mycobacterial cell surface [145].

The mycolic acids that are bound to the cell wall arabinogalactan form the inner part of an outer membrane that allows adhesion at an oil-water interface to facilitate feeding from oils and fats. This property gave Rhodococcus species potential for industrial application to clean up sites of oil pollution [137]. In Mycobacterium tuberculosis, this property is manifested as an ability to attract cholesterol into the lipid-free zone that surrounds the cell wall mycolic acid layer [146] and is at the basis of the requirement for host cell membrane cholesterol to enable entry of the bacillus into its host macrophage $[139,147]$. Besides being essential for the phagocytosis of the bacterium by the macrophage, cholesterol is also used by the bacilli as an energy and carbon source that is critically linked with mycobacterial persistence $[148,149]$ and depends on a sufficient availability of the sterol within the host cell. Mycolic acids may in fact constitute a direct means by which intracellular $M$. tuberculosis bacilli ensure a sufficient lipid import by the host macrophage. The property of MA to 
attract cholesterol may mean that free MA, known to be released from the bacilli for the purpose of biofilming $[15,122]$, could fulfil the role of attracting cholesterol into the biofilm as a carbon source for the slow growing, persistent mycobacteria. Cholesterol is known to be able to diffuse across biological membranes along a concentration gradient without the need for specific transport mechanisms. It is therefore the ideal carbon source for a pathogen that survives by isolating itself from the host vasculature that normally provides for the pathogen's nutrient requirements. Should the mycolic acids be able also to attract cholesterol in vivo, then their function in the biofilm may well include the creation of the cholesterol concentration gradient necessary to facilitate cholesterol transfer from host to pathogen. Brzostek et al. [146] demonstrated that the ability of M. tuberculosis to attract cholesterol close to its cell wall depended on the presence of the extractable lipid component of the cell wall, which includes the free mycolic acids and the trehalose mycolates from which they are released [122].

In their pioneering paper, Korf and colleagues [108] were the first to demonstrate that mycolic acids strongly interfered with the lipid metabolism of mouse macrophages, triggering intracellular accumulation of cholesterol, increased cell size, and multiple vacuole formation, all typical features of macrophage foam cells. Foamy macrophages containing multiple cholesterol loaded lipid bodies constitute a distinct trait of tuberculous granulomas and a safe haven for mycobacteria, since they have been found to harbor multiple bacilli $[150,151]$. Induction by mycolic acids of macrophages rich in lipid bodies was further confirmed on human monocyte-derived macrophages [152]. Here, the authors further showed that oxygenated mycolic acids, mostly of the keto class, play a leading role in the observed foamy macrophage formation.

In non-pathological conditions, macrophage lipid import and export are tightly regulated processes. Excessive cholesterol accumulation therefore is indicative of a disturbed lipid homeostasis in the cells. Liver X receptors (LXRs), LXR $\alpha$ and LXR $\beta$, are master regulators of macrophage transcriptional programs involved in cholesterol homeostasis [153, 154, 155]. LXR activation by oxidized forms of cholesterol (oxysterols) induces expression of several genes involved in cholesterol trafficking and efflux, such as $A B C A 1, A B C G 1 / A B C G 4$, and apoE $[156,157]$. An increased cholesterol influx and accumulation in infected macrophages may as a consequence trigger the activation of LXR nuclear receptors and LXR target genes. This was recently confirmed using a mouse model of $M$. tuberculosis pulmonary infection. Here, alveolar macrophages isolated from the bronchoalveolar lavage and lung tissue showed besides an increased expression of the inducible $L X R \alpha$ isoform also increased expression levels of the LXR $\alpha \square \operatorname{target~genes,~} A B C A 1$, apoE and SREBP-1c [158]. This infection-induced activation of LXR $\alpha$ transcriptional activity may be of direct relevance for the course of the infection. Thus mice deficient in $L X R \alpha$ showed an increased susceptibility to infection, developing higher bacterial burdens and an increase in size and number of granulomatous lesions. This increased susceptibility was accompanied by a failure of the $L X R \alpha^{-/-}$mice to mount an 
effective early neutrophilic airway response and, at a later stage, by a near-complete abrogation of the infection-induced $\mathrm{Th}_{1}$ and $\mathrm{Th}_{17}$ response in the lungs [158]. Whereas these immune consequences of a deficient LXR $\alpha$ function obviously may directly contribute to the increased susceptibility of the mice, it is noteworthy that mice deficient in $L X R \alpha$ also accumulate intracellular cholesterol within tissue macrophages, resulting in a foamy macrophage-like morphotype (Unpublished results). It can therefore not be excluded that the increased intracellular cholesterol content in $L X R \alpha^{-/}$macrophages, comparable to the cholesterol-loaded foamy macrophages induced by mycolic acids, generates an energy-rich environment for the bacilli, promoting M. tuberculosis persistence and indirectly contributing in $L X R \alpha^{--}$mice to increased susceptibility.

The cholesteroid antigenic nature of MA may add to the propensity of forming energy rich foamy macrophages at the site of mycobacterial infection to benefit the parasitic bacilli [159]. Thus it is possible that the antibodies to MA that are cross-reactive with cholesterol may behave as anticholesterol antibodies do: at high concentration the latter are known to bind to VLDL/IDL and LDL, but not to HDL [160]. This was found to be due to the higher concentration of non-esterified cholesterol on the surface of VLDL/IDL and LDL in comparison to that on HDL. In the body, this function relates to the role that HDL plays in sequestering cholesterol from the surfaces of cells for transport to the liver, while VLDL and LDL have the function to distribute cholesterol from the intestines and liver to the tissues. Antibody opsonized lipoproteins of the VLDL or LDL type will then be selectively phagocytosed by macrophages through the Fc receptors, thereby creating or adding to the lipid abundance of such cells to support the parasitic growth of the mycobacteria on a mainly cholesterol diet.

\section{Conclusion}

From simple, short chained MAs with one or a few unsaturated bonds in Corynebacterium to long chain MAs of Mycobacterium endowed with chiral functional groups, nature displays how a bacterial wax is phylogenetically developed from just being a cell wall barrier against the environment (Corynebacterium, Rhodococcus, Nocardia) to a sophisticated, conformationally sensitive, pleiotropic cell wall system (Mycobacterium) designed to also direct cellular host-pathogen relationships and steer host immunity to benefit the survival of the prokaryotic parasite. Besides the proven role of various aspects of function of MA in defining virulence of mycobacterial pathogens, mainly demonstrated by recombinant mutants of mycobacteria that are defective in some aspect of decoration of MA with functional groups during biosynthesis, free mycolic acids that are released from sites of infection elicit immunity in a structure dependent way. Mycobacterial MAs elicit both innate immune steering mechanisms and adaptive humoral and cellular immunity. Innate immunity to MA exposure is characterized by granulocyte, macrophage and dendritocyte activity with specific cytokine responses to steer immunity. Adaptive immunity to MA is characterized by B cells producing IgG 
antibodies to MA and by $\mathrm{T}$ cells of both the effector and memory type coming about and responding to MA in rapid expansion upon reencounter of MA. We have reviewed the evidence that the innate immune response to MA is differentiated into MA class specific activities, such as neutrophil attraction by methoxy-MA and macrophage foam cell induction by keto-MA. Likewise, the adaptive antibody response to MA is differentiated into high antigenicity (methoxy-MA) and low antigenicity (alpha-MA), of which all are responsive to the stereochemical configuration around the functional groups of MA.

How this knowledge can be exploited for intervention of tuberculosis in the management of the global TB epidemic depends on a better understanding of the role of MA elicited immune responses in protection of the host, prevention of auto-immunity or parasite beneficiation. Brigl and Brenner in 2004 [161] reviewed evidence of several examples of where CD1 restricted immune responses are involved in various auto-immune diseases, both in infectious and non-infectious disease conditions. Although much more is known about Group II CD1d restricted responses in auto-immunity, Group I restricted $\mathrm{T}$ cell involvement has also been reported for auto-immune related diseases, particularly in inflammatory neuropathies and rheumatoid arthritis. Thus, the potential for using MAs as a treatment for asthma, demonstrated in mice by Korf et al. in 2006 [116], awaits an understanding of how administered MAs affect auto-immunity, disease susceptibility or other essential pathways of metabolism. Diagnosis of TB by means of biomarker anti-MA antibody detection in patients [92] awaits a better understanding of the cross-reactivity of such antibodies with cholesterol and the binding properties of the universally prevalent interfering anti-cholesterol antibodies in humans. The inclusion of MA in anti-TB vaccines [89] awaits the understanding of whether the MA reactive memory and effector $\mathrm{T}$ cells actually protect against $\mathrm{TB}$.

The discovery of the cholesteroid nature of MA reviewed here provides a strong clue to the better understanding of how mycolic acids contribute to establish tuberculosis, in particular how free mycolic acids may influence the availability of cholesterol as a prime nutrient for mycobacteria in persistent TB and how the induction of cholesterol cross-reactive anti-MA antibodies may aid towards the delivery of cholesterol to sites of infection.

\section{Acknowledgements}

The authors are supported by Grants from the Wellcome Trust (085656/Z/08/Z); Asthma UK (08/053), Research Foundation-Flanders (G.0376.05N; G.0063.09N) and South African National Research Foundation (CPR73712). 


\section{References}

[1] Anderson RJ. The separation of lipoid fractions from tubercle bacilli. J Biol Chem 1927; 74: 525535 .

[2]Gebhardt H, Meniche X, Tropis M, Krämer R, Daffé M, Morbach S. The key role of the mycolic acid content in the functionality of the cell wall permeability barrier in Corynebacterineae.

Microbiology 2007; 153:1424-1434.

[3] Portevin D, De Sousa-D'Auria C, Houssin C, Grimaldi C, Chami M, Daffé M, Guilhot C. A polyketide synthase catalyzes the last condensation step of mycolic acid biosynthesis in mycobacteria and related organisms. Proc. Natl. Acad. Sci. USA 2004; 101:314-319.

[4] Vilcheze C, Morbidoni HR, Weisbrod TR, Iwamoto H, Kuo M, Sacchetini JC, Jacobs WR Jr. (). Inactivation of the inhA-encoded fatty acid synthase II (FASII) enoyl-acyl carrier protein reductase induces accumulation of the FASI end products and cell lysis of Mycobacterium smegmatis. $J$ Bacteriol 2000; 182: 4059-4067.

[5] Sutcliffe IC. Cell envelope composition and organisation in the genus Rhodococcus. Antonie Van Leeuwenhoek 1998; 74: 49-58.

[6] Nishiuchi Y, Baba T, Hotta HH, Yano I. Mycolic acid analysis in Nocardia species: The mycolic acid compositions of Nocardia asteroides, N. farcinica, and N. nova. J Microbiol Methods 1999; 37: $111-122$.

[7] Lichtinger T, Reiss G, Benz R. Biochemical identification and biophysical characterization of a channel-forming protein from Rhodococcus erythropolis. J Bacteriol 2000; 182: 764-770.

[8] Hsu F, Soehl K, Turk J, Haas A. Characterization of mycolic acids from the pathogen Rhodococcus equi by tandem mass spectrometry with electrospray ionization. Anal Biochem 2011; 409:112-122.

[9] Dao ND, Sweeney K, Hsu T, Gurcha SS, Nascimento IP, RoshevskyD, Besra GS, Chan J, Porcelli SA, Jacobs WR. Mycolic acid modification by the mma4 gene of M.tuberculosis modulates IL-12 production. PLOS Pathog 2008; 4: e1000081.

[10] Glickman MS. The mmaA2 gene of Mycobacterium tuberculosis encodes the distal cyclopropane synthase of the alpha-mycolic acid. J Biol Chem 2003; 278: 7844-7849.

[11] Glickman MS, Cox JS, Jacobs WR Jr. A novel mycolic acid cyclopropane synthetase is required for cording, persistence, and virulence of Mycobacterium tuberculosis. Mol Cell 2000; 5: 717-727.

[12] Glickman MS, Cahill SM, Jacobs WR Jr. The Mycobacterium tuberculosis cmaA2 gene encodes a mycolic acid trans-cyclopropane synthetase. J Biol Chem 2001; 276: 2228-2233.

[13] Behr MA, Schroeder BG, Brinkman J N, Slayden RA, Barry CE 3rd. A point mutation in the mma3 gene is responsible for impaired methoxymycolic acid production in Mycobacterium bovis BCG strains obtained after 1927. J Bacteriol 2000; 182: 3394-3399. 
[14] Dubnau E, Chan J, Raynaud C, Mohan VP, Lanéelle MA, Yu K, Quemard A, Smith I, Daffé M. Oxygenated mycolic acids are necessary for virulence of Mycobacterium tuberculosis in mice. Mol Microbiol 2000; 36: 630-637.

[15] Ojha AK, Baughn AD, Sambandan D, Hsu T, Trivelli X, Guerardel Y, Alahari A, Kremer L, Jacobs WR Jr, Hatfull GF. Growth of Mycobacterium tuberculosis biofilms containing free mycolic acids and harbouring drug-tolerant bacteria. Mol Microbiol 2008; 69: 164-174.

[16] Asselinau J, Lederer E. Summarised in Fortschr Chem Org Naturstoffe 1953; 10: 170.

[17] Etémadi AH,Lederer E. Sur la structure des acides a-mycoliques de la souche humaine 'Test' de Mycobacterium tuberculosis. Bull Soc Chim Fr; 1965: 2640-2645.

[18] Minnikin DE, Polgar N. Studies of the mycolic acids from human tubercle bacilli. Tetrahedron Letts 1966; 7: 2643-2647.

[19] Minnikin DE, Polgar N. Structural studies on the mycolic acids. J Chem Soc Chem Comm 1967; 312-313.

[20] Asselineau, C, Asselineau. J Bull Soc Chim Fr 1966 ; 1992.

[21] Minnikin DE, Polgar N. Stereochemical studies on the mycolic acids. J Chem Soc Chem Comm 1966; 648-649.

[22] Minnikin, DE, Polgar, N. The mycolic acids from human and avian tubercle bacilli. J Chem Soc Chem Comm 1967; 916-917.

[23], Minnikin DE, Polgar N. The methoxymycolic and ketomycolic acids from human tubercle bacilli. J Chem Soc Chem Comm 1967; 1172-1173.

[24] Watanabe M, Aoyagi Y, Ridell M, Minnikin DE. Separation and characterisation of individual mycolic acids in representative mycobacteria. Microbiol 2001; 147: 1825-1837.

[25] Watanabe M, Aoyagi Y, Mitome H, Fujita T, Naoki H, Ridell M, Minnikin DE. Location of functional groups in mycobacterial meromycolate chains; the recognition of new structural principles in mycolic acids. Microbiol 2002; 148: 1881-1902.

[26] Davidson LA, Draper P, Minnikin DE. Studies on the mycolic acids from the walls of Mycobacterium microti. J Gen Microbiol 1982; 128: 823-828.

[27] Laval F, Lanéelle M-A, Deon C, Monsarrat B, Daffé M. Accurate molecular mass determination of mycolic acids by MALDI-TOF mass spectrometry. Anal Chem 2001; 73: 4537-4544.

[28] Uenishi Y, Fujita Y, Kusunose N, Yano I, Sunagawa M. Comprehensive analysis of mycolic acid subclass and molecular species composition of Mycobacterium bovis BCG Tokyo 172 cell wall skeleton (SMP-105) J Microbiol Methods 2008; 72: 149-156.

[29] Lanéelle MA, Lanéelle G. Structure d'acides mycoliques et d'un intermediaire dans la biosynthese d'acides mycoliques dicarboxyliques. Eur J Biochem 1970; 12 : 296-300.

[30] Krembel J, Etémadi A-H, Sur la structure d'un nouveau type d'acides mycoliques de Mycobacterium smegmatis. Tetrahedron $1966 ; 22: 1113-1119$. 
[31] Wong MYH, Gray GR. Structures of the homologous series of monoalkene mycolic acids from Mycobacterium smegmatis. J Biol Chem 1979; 254: 5741-5744.

[32] Wong MYH, Steck PA, Gray GR. The major mycolic Acids of Mycobacterium smegmatis. J Biol Chem 1979; 254: 5734-5740.

[33] Danielson SJ, Gray GR. Structures of the two homologous series of dialkene mycolic acids from Mycobacterium smegmatis. J Biol Chem 1982; 257: 12196-12303.

[34] Daffé M, Lanéelle M-A, Valero-Guillen PL. Tetraenoic and pentaenoic mycolic acids from Mycobacterium thamnepheos. Eur J Biochem 1988; 177: 339-344.

[35] Lanéelle MA, Lacave C, Daffé M, Lanéelle G. Mycolic acids of Mycobacterium aurum. Eur J Biochem 1988; 177: 631-635.

[36] Lacave C, Lanéelle M-A, Daffé M, Montrozier H, Lanéelle G. Mycolic acid metabolic filiation and location. Eur J Biochem 1989; 181: 459-466.

[37] Daffé M, Lanéelle MA, Puzo G, Asselineau C. Acide mycolique epoxydique: un nouveau type d'acide mycolique. Tetrahedron Letts 1981; 21:4515-4516.

[38] Luquin M, Lanéelle MA, Ausina V, Barcelo MG, Belda F, Alonso C, Prats G. Distribution of a novel mycolic acid in species of the genus Mycobacterium. Int J System Bact 1991; 2000: 390-394.

[39] Laval F, Haites R, Movahedzadeh F, Lemassu A, Wong CY, Stoker N, Billman-Jacobe H, Daffé $\mathrm{M}$. Investigating the function of the putative mycolic acid methyltransferase UmaA: Divergence between the Mycobacterium smegmatis and Mycobacterium tuberculosis proteins. J Biol Chem 2008; 283: 1419-1427.

[40] Minnikin DE, Minnikin SE, Parlett JH, Goodfellow M, Magnusson M. Mycolic acid patterns of some species of Mycobacterium. Arch Microbiol 1984; 139: 225-231.

[41] Yassin AF, Binder C, Schaal KP. Identification of mycobacterial isolates by thin-layer and capillary gas-liquid-chromatography under diagnostic routine conditions. Int J Med Microbiol Vir Par Inf Dis 1993; 278: 34-48.

[42] Qureshi N, Takayama K, Jordi HC, Schnoes HK. Characterization of the purified components of a new homologous series of alpha-mycolic acids from Mycobacterium tuberculosis H37Ra. J Biol Chem 1978; 253: 5411-5417.

[43] Butler WR, Guthertz LS. Mycolic acid analysis of high-performance liquid chromatography for identification of Mycobacterium species. Clin Microbiol Rev; 2001: 704-726.

[44] Hagen SR, Tompson JD. Analysis of mycolic acids by high-performance liquid chromatography and fluorimetric detection. Implications for the identification of mycobacteria in clinical samples. $\mathrm{J}$ Chrom 1995; 692: 167-172.

[45] Floyd MM, Wilcox VA, Jones WD, Butler WR, Kilburn JO. Separation of Mycobacterium bovis $B C G$ from Mycobacterium tuberculosis and Mycobacterium bovis by using high-performance liquid chromatography of mycolic acids. J Clin Microbiol 1992; 30: 1327-1330.

[46] Butler WR, O'Connor SP, Yakrus MA, Smithwick RW, Plikaytis BB, Moss CW, Floyd MM, Woodley CL, Kilburn JO, Vadney FS. Mycobacterium celatum sp. Nov. Int J Syst Bacteriol 1993; 43: 539-548. 
[47] Shui G, Bendt AK, Pethe K, Dick T, Wenk MR. Sensitive profiling of chemically diverse bioactive lipids. J Lipid Res 2007; 48: 1976-1984.

[48] Noll H, Bloch H. Studies on the cord factor of Mycobacterium tuberculosis. J Biol Chem 1955; 214: $251-265$

[49] Adam A, Senn M, Lederer E. Spectrometrie de masse de glycolipides 2. Diesters de trehalose naturels et synthetiques. Eur J Biochem 1967; 2: 460-468.

[50] Ryll R, Kumazawa Y, Yano I. Immunological properties of trehalose dimycolate (cord factor) and other mycolic acid-containing glycolipids - A review. Microbiol Immunol 2001; 45: 801-811.

[51] Fujiwara N. Distribution of antigenic glycolipids among Mycobacterium tuberculosis strains and their contribution to virulence. Kekkaku 1997; 72: 193-205.

[52] Fujita Y, Naka T, Doi T, Yano I. Direct molecular mass determination of trehalose monomycolate from 11 species of mycobacteria by MALDI-TOF mass spectrometry. Microbiol 2005; 151: $1443-1452$.

[53] Fujita Y, Naka T, McNeil MR, Yano I. Intact molecular characterization of cord factor (trehalose 6,6 '-dimycolate) from nine species of mycobacteria by MALDI-TOF mass spectrometry. Microbiol 2005 ; 151: 3403-3416.

[54] Kai M, Fujita Y, Maeda Y, Nakata,N, Izumi, S, Yano, I, Makino, M. Identification of trehalose dimycolate (cord factor) in Mycobacterium leprae. FEBS Letts 2007; 581: 3345-3350.

[55] Al Dulayymi JR, Baird MS, Maza-Iglesias M, Vander Beken S, Grooten J. The first unique synthetic mycobacterial cord factors. Tetrahedron Letts 2009; 50: 3702-3705.

[56] Moody DB, Reinhold BB, Guy MR, Beckman EM, Frederique DE, Furlong ST, Ye S, Reinhold VN, Sieling PA, Modlin RL, Besra G, Porcelli SA. Structural requirements for glycolipid antigen recognition by CD1b-restricted T cells. Science 1997; 278: 283-286.

[57] Moody DB, Guy MR, Grant E, Cheng T-Y, Brenner MB, Besra GS, Porcelli SA. CD1b-mediated $\mathrm{T}$ cell recognition of a glycolipid antigen generated from mycobacterial lipid and host carbohydrate during infection. J Exp Med 2000; 192: 965-976.

[58] Enomoto Y, Sugita M, Matsunaga I, Naka T, Sato A, Kawashima T, Shimizu K, Takahashi H, Norose Y, Yano I. Temperature-dependent biosynthesis of glucose monomycolate and its recognition by CD1-restricted T cells. Biochem Biophys Res Comm 2005; 337: 452-456.

[59] Watanabe M, Ohta A, Sasaki S-I, Minnikin DE. Structure of a new glycolipid from the Mycobacterium avium-Mycobacterium intracellulare complex. J Bacteriol 1999; 181: 2293-2297.

[60] Andersen CS, Agger EM, Rosenkrands I, Gomes JM, Bhowruth V, Gibson KJC, Petersen RV, Minnikin DE, Besra GS, Andersen P. A simple mycobacterial monomycolated glycerol lipid has potent immunostimulatory activity. J Immunol 2009; 182: 424-432.

[61] Yuan Y, Barry CE. A common mechanism for the biosynthesis of methoxy and cyclopropyl mycolic acids in Mycobacterium tuberculosis. Proc Natl Acad Sci USA 1996; 93: 12828-12833.

[62] Dubnau E, Lanéelle M-A, Soares S, Bénichou A, Vaz T, Promé D, Promé J-C, Daffé M, Quémard A. Mycobacterium bovis BCG genes involved in the biosynthesis of cyclopropyl keto-and hydroxy-mycolic acids Mol Microbiol 1997; 23: 313-322. 
[63] Quémard A, Lanéelle MA, Marrakchi H, Promé D, Dubnau E, Daffé M. Structure of a hydroxymycolic acid potentially involved in the synthesis of oxygenated mycolic acids of the Mycobacterium tuberculosis complex. Eur J Biochem 1997; 250: 758-763.

[64] Al Dulayymi JR, Baird MS, Roberts E. The synthesis of a single enantiomer of a major alphamycolic acid of M. tuberculosis. Tetrahedron 2005; 61: 11939-11951.

[65] Alibaud L, Alahari A, Trivelli X, Ojha AK, Hatfull GF, Guerardel Y, Kremer L. Temperaturedependent regulation of mycolic acid cyclopropanation in saprophytic mycobacteria: Role of the Mycobacterium smegmatis 1351 gene (MSMEG_1351) in cis-cyclopropanation of $\alpha$-mycolates. J Biol Chem 2010; 285: 21698-21707.

[66] Al Dulayymi JR, Baird MS, Roberts E, Deysel M, Verschoor JA. The first syntheses of single enantiomers of the major methoxymycolic acid of Mycobacterium tuberculosis. Tetrahedron 2007; 63: 2571-2592.

[67] Koza G, Theunissen C, Al Dulayymi JR, Baird MS. The synthesis of single enantiomers of mycobacterial ketomycolic acids containing cis-cyclopropanes. Tetrahedron 2009; 65: 10214-10229.

[68] Al Dulayymi JR, Baird MS, Mohammed H, Roberts E, Clegg W. The synthesis of one enantiomer of the alpha-methyl-trans-cyclopropane unit of mycolic acids. Tetrahedron 2006; 62: 4851-4862.

[69] Muzael M, Koza G, Al Dulayymi JR, Baird MS. The synthesis of a major alpha'-mycolic acid of Mycobacterium smegmatis. Chem Phys Lipids 2010; 163: 678-684.

[70] Koza G, Rowles R, Theunissen C, Al Dulayymi JR, Baird MS. The synthesis of single enantiomers of trans-alkene-containing mycolic acids. Tetrahedron Letts 2009; 50: 7259-7262.

[71] Al Kremawi DZ, Al Dulayymi JR, Baird MS. The first synthesis of epoxy-mycolic acids. Tetrahedron Letts 2010; 51: 1698-1701.

[72] Toriyama S, Yano I, Masui M, Kusunose E, Kusunose M, Akimori N. Regulation of cell wall mycolic acid biosynthesis in acid-fast bacteria: I. Temperature-induced changes in mycolic acid molecular species and related compounds in Mycobacterium phlei. J Biochem 1980; 88: 211-221.

[73] Liu J, Barry CE, Besra GS, Nikaido H. Mycolic acid structure determines the fluidity of the mycobacterial cell wall. J Biol Chem 1996; 271: 29545-29551.

[74] Yuan Y, Crane DC, Musser JM, Sreevatsan S, Barry CE. MMAS-1, the branch point between cis- and trans-cyclopropane-containing oxygenated mycolates in Mycobacterium tuberculosis. J Biol Chem 1997; 272: 10041-10049.

[75] Rao V, Fujiwara N, Porcelli SA. Mycobacterium tuberculosis controls host innate immune activation through cyclopropane modification of a glycolipid effector molecule. J Exp Med 2005; 201: 535-543.

[76] Rao V, Gao F, Chen B, Jacobs WR, Glickman MS. Trans-cyclopropanation of mycolic acids on trehalose dimycolate suppresses Mycobacterium tuberculosis-induced inflammation and virulence. J Clin Invest 2006; 116: 1660-1667.

[77] Riley LW. Of mice, men, and elephants: Mycobacterium tuberculosis cell envelope lipids and pathogenesis. J Clin Invest 2006; 116: 1475-1478. 
[78] Beckman EV, Porcelli SA, Morita CT, Behar SM, Furlong ST, Brenner MB. Recognition of a lipid antigen by CD1-restricted $\alpha \beta^{+}$T cells. Nature 1994; 372: $691-694$.

[79] Cohen NR, Garg S, Brenner MB. Antigen Presentation by CD1: Lipids, T Cells, and NKT Cells in Microbial Immunity. Adv Immunol 2009; 102: 1-94.

[80] Facciotti F, Cavallari M, Angénieux C, Garcia-Alles L-F, Signorino-Gelo F, Angman L, Gilleron M, Prandi J, Puzo G, Panza L, Xia C, Wang PG, Dellabona P, Casorati G, Porcelli SA, De la Salle H, Mori L, De Libero G. Fine tuning by human CD1e of lipid-specific immune responses. Proc Natl Acad Sci (USA) 2011; 108: 14228-14233.

[81] Prigozy TI, Naidenko O, Qasba P, Elewaut D, Brossay L, Khurana A, Natori T, Koezuka Y, Kulkarni A, Kronenberg M. Glycolipid antigen processing for presentation by CD1d molecules. Science 2001; 291: 664-667.

[82] De la Salle H, Mariotti S, Angenieux C, Gilleron M, Garcia-Alles L-F, Malm D, Berg T, Paoletti S, Maître B, Mourey L, Salamero J, Cazenave JP, Hanau D, Mori L, Puzo G, De Libero G. Assistance of microbial glycolipid antigen processing by CD1e. Science 2005; 310: 1321-1324.

[83] Ulrichs T, Moody DB, Grant E, Kaufmann SH, Porcelli SA. T-cell responses to CD1-presented lipid antigens in humans with Mycobacterium tuberculosis infection. Infect Immun 2003; 71: 3076-87.

[84] Brigl M, van den Elzen P, Chen X, Meyers JH, Wu D, Wong CH, Reddington F, Illarianov PA, Besra GS, Brenner MB, Gumperz JE. Conserved and heterogeneous lipid antigen specificities of CD1drestricted NKT cell receptors. J Immunol 2006; 176: 3625-34.

[85] Jayawardena-Wolf J, Bendelac A. CD1 and lipid antigens: intracellular pathways for antigen presentation. Curr Opin Immunol 2001; 13:109-113.

[86] Porcelli SA, Modlin R. The CD1 system: antigen presenting moleculesfor T cell recognition of lipids and glycolipids. Annu Rev Immunol 1999; 17:297-329.

[87] Stenger S, Mazzaccaro RJ, Uyemura K, Cho S, Barnes PF, Rosat JP, Sette A, Brenner MB, Porcelli SA, Bloom BR, Modlin RL. Differential effects of cytolytic T cell subsets on intracellular infection. Science 1997; 276:1684-1687.

[88] Goodrum, MA, Siko DGR, Niehues T, Eichelbauer D \& Verschoor JA. Mycolic acids from Mycobacterium tuberculosis: purification by countercurrent distribution and T cell stimulation.

Microbios 2001; 106: 55-67.

[89] Montamat-Sicotte DJ, Millington KA, Willcox CR, Hingley-Wilson S, Hackforth S, Innes J, Kon OM, Lammas DA, Minnikin DE, Besra GS, Willcox BE, Lalvani A. A mycolic acid-specific CD1restricted $\mathrm{T}$ cell population contributes to acute and memory immune responses in human tuberculosis infection. J Clin Invest 2011; 121: 2493-2503.

[90] Sieling PA, Porcelli SA, Duong BT, Spada F, Bloom BR, Diamond B, Hahn BH. Human double negative T cells in Systemic Lupus Erythematosus provide help for IgG and are restricted by CD1c. J Immunol 2000; 165: 5338-5344. 
[91] Gilleron M, Stenger S, Mazorra Z, Wittke F, Mariotti S, Böhmer G, Prandi J, Mori L, Puzo G, De Libero G. Diacylated sulfoglycolipids are novel mycobacterial antigens stimulating CD1-restricted T cells during infection with Mycobacterium tuberculosis. J Exp Med 2004; 199: 649-59.

[92] Thanyani ST, Roberts VV, Siko DGR, Vrey P, Verschoor JA. A novel application of affinity biosensor technology to detect antibodies to mycolic acid in tuberculosis patients. J Immunol Methods 2008; 332: 61-72.

[93] Dorhoi A, Reece ST, Kaufmann SHE. For better or for worse: the immune response against Mycobacterium tuberculosis balances pathology and protection. Immunol Rev 2011; 240: 235-251.

[94] Cooper AP. Cell-Mediated Immune Responses in Tuberculosis. Annu Rev Immunol 2009; 27: $393-422$.

[95] Brennan PJ. Structure, function and biogenesis of the cell wall of Mycobacterium tuberculosis. Tuberculosis 2003; 83: 91-97.

[96] Tsuji S, Matsumoto M, Takeuchi O, Akira S, Azuma I, Hayashi A, Toyoshima K, Seya T. Maturation of human dendritic cells by cell wall skeleton of Mycobacterium bovis bacillus CalmetteGuerin: involvement of toll-like receptors. Infect Immun 2000; 68: 6883-6890.

[97] Means TK, Wang S, Lien E, Yoshimura A, Golenbock DT, Fenton MJ. Human toll-like receptors mediate cellular activation by Mycobacterium tuberculosis. J Immunol 1999; 163: 3920-3927.

[98] Uehori J, Matsumoto M, Tsuji S, Akazawa T, Takeuchi O, Akira S, Kawata T, Azuma I, Toyoshima K, Seya T. Simultaneous Blocking of Human Toll-Like Receptors 2 and 4 Suppresses Myeloid Dendritic Cell Activation Induced by Mycobacterium bovis Bacillus Calmette-Guérin Peptidoglycan. Infect Immun 2003; 71: 4238-4249.

[99] Means TK, Lien E, Yoshimura A, Wang S, Golenbock DT, Fenton M J. The CD14 ligands lipoarabinomannan and lipopolysaccharide differ in their requirement for Toll-like receptors. J Immunol 1999; 163: 6748-6755.

[100] Chatterjee D, Roberts AD, Lowell K, Brennan PJ, Orme IM. Structural basis of capacity of lipoarabinomannan to induce secretion of tumor necrosis factor. Infect Immun 1992; 60: 1249-1253.

[101] Indrigo J, Hunter Jr RL, Actor JK. Influence of trehalose 6,60-dimycolate (TDM) during mycobacterial infection of bone marrow macrophages. Microbiology 2002; 148: 1991-1998.

[102] Indrigo J, Hunter Jr RL, Actor JK. Cord factor trehalose 6,60-dimycolate (TDM) mediates trafficking events during mycobacterial infection of murine macrophages. Microbiology 2003; 149: 2049-2059.

[103] Quesniaux VJ, Nicolle DM, Torres D, Kremer L, Guérardel Y, Nigou J, Puzo G, Erard F, Ryffel B. Toll-like receptor 2 (TLR2)-dependent-positive and TLR2-independent-negative regulation of proinflammatory cytokines by mycobacterial lipomannans. J Immunol 2004; 172: 4425-4434.

[104] Brightbill HD, Libraty DH, Krutzik SR, Yang RB, Belisle JT, Bleharski JR, Maitland M, Norgard MV, Plevy SE, Smale ST, Brennan PJ, Bloom BR, Godowski PJ, Modlin RL. Host defense mechanisms triggered by microbial lipoproteins through toll-like receptors. Science 1999; 285: 732736.

[105] Goren MB, Broki O, Das BC. Sulfatides of Mycobacterium tuberculosis: the structure of the principal sufatide (SL-1). Biochemistry 1976; 15: 2728-2735. 
[106] Camacho LR, Constant P, Raynaud C, Laneelle MA, Triccas JA, Gicquel B, Daffé M, Guilhot C. Analysis of the phthiocerol dimycocerosate locus of Mycobacterium tuberculosis. Evidence that this lipid is involved in the cell wall permeability barrier. J Biol Chem 2001;276:19845-19854.

[107] Cox JS, Chen B, McNeil M, Jacobs Jr WR. Complex lipid determines tissue-specific replication of Mycobacterium tuberculosis in mice. Nature 1999; 402: 79-83.

[108] Korf J, Stoltz A, Verschoor J, De Baetselier P, Grooten J. The Mycobacterium tuberculosis cell wall component mycolic acid elicits pathogen-associated host innate immune responses. Eur $\mathrm{J}$ Immunol 2005; 35: 890-900.

[109] Vergne I, Chua J, Deretic V. Tuberculosis toxin blocking phagosome maturation inhibits a novel Ca2+/calmodulin-PI3K hVPS34 cascade. J Exp Med 2003; 198:653-659.

[110] Vergne I, Chua J, Lee HH, Lucas M, Belisle J, Deretic V. Mechanism of phagolysosome biogenesis block by viable Mycobacterium tuberculosis. Proc Natl Acad Sci U S A. 2005; 102: 40334038.

[111] Borelli V, Banfi E, Perrotta MG, Zabucchi G. Myeloperoxidase exerts microbicidal activity against Mycobacterium tuberculosis. Infect Immun 1999; 67: 4149-4152.

[112] Fenhalls G, Wong A, Bezuidenhout J, van Helden P, Bardin P, Lukey PT. In situ production of gamma interferon, interleukin-4, and tumor necrosis factor alpha mRNA in human lung tuberculous granulomas. Infect Immun 2000; 68: 2827-2836.

[113] Chu EK, Drazen JM. Asthma: one hundred years of treatment and onward. Am J Respir Crit Care Med 2005; 171: 1202-1208.

[114] Bogaert P, Tournoy KG, Naessens T, Grooten J. Where asthma and hypersensitivity pneumonitis meet and differ: noneosinophilic severe asthma. Am J Pathol 2009; 174: 3-13.

[115] Jones PD, Gibson PG, Henry RL. The prevalence of asthma appears to be inversely related to the incidence of typhoid and tuberculosis: hypothesis to explain the variation in asthma prevalence around the world. Med Hypotheses 2000; 55: 40-42.

[116] Korf JE, Pynaert G, Tournoy K, Boonefaes T, Van Oosterhout A, Ginneberge D, Haegeman A, Verschoor JA, De Baetselier P, Grooten J. Macrophage reprogramming by mycolic acid promotes a tolerogenic response in experimental asthma. Am J Respir Crit Care Med 2006; 174: 152-160.

[117] Vander Beken S, Al Dulayymi JR, Naessens T, Koza G, Maza-Iglesias M, Rowles R, Theunissen C, De Medts J, Lanckacker E, Baird MS, Grooten J. Molecular structure of the Mycobacterium tuberculosis virulence factor, mycolic acid, determines the elicited inflammatory pattern. Eur J Immunol 2011; 41: 450-460.

[118] Flores-Valdez MA, Morris RP, Laval F, Daffé M, Schoolnik GK. Mycobacterium tuberculosis modulates its cell surface via an oligopeptide permease (Opp) transport system. FASEB J 2009; 23: 4091-4104.

[119] Ryan GJ, Hoff DR, Driver ER, Voskuil MI, Gonzalez-Juarrero M, Basaraba RJ, Crick DC, Spencer JS, Lenaerts AJ. Multiple M. tuberculosis phenotypes in mouse and guinea pig lung tissue revealed by a dual-staining approach. PLoS ONE 2010; 5: e11108. 
[120] Ojha A, Anand M, Bhatt A, Kremer L, Jacobs Jr WR, Hatfull GF. GroEL1: A dedicated chaperone involved in mycolic acid biosynthesis during biofilm formation in mycobacteria. Cell 2005; 123: 861-873.

[121] Lenaerts AJ, Hoff D, Aly S, Ehlers S, Andries K, Cantarero L, Orme IM, Basaraba R J. Location of persisting mycobacteria in the guinea pig model of tuberculosis revealed by R207910. Antimicrob Agents Chemother 2007; 51: 3338-3345.

[122] Ojha AK, Trivelli X, Guerardel Y, Kremer L, Hatfull GF. Enzymatic hydrolysis of trehalose dimycolate releases free mycolic acids during mycobacterial growth in biofilms. J Biol Chem 2010; 285: 17380-17389.

[123] Takeuchi O, Akira S. Pattern recognition receptors and inflammation. Cell 2010; 140: 805-820.

[124] Martinon F, Mayor A, Tschopp J. The inflammasomes: guardians of the body. Ann Rev Immunol 2009; 27: 229-265.

[125] Pan, J., Fujiwara, N., Oka, S., Maekura, R., Ogura, T., Yano, L. (1999). Anti-Cord Factor (Trehalose 6,6'-Dimycolate) IgG antibody in tuberculosis patients recognizes mycolic acid subclasses. Microbiol Immunol 43, $863-869$.

[126] Beukes M, Lemmer Y, Deysel M, Al Dulayymi JR, Baird MS, Koza G, Iglesias MM, Rowles RR, Theunissen C, Grooten J, Toschi G, Roberts VV, Pilcher L, Van Wyngaardt S, Mathebula N, Balogun M, Stoltz AC, Verschoor JA. Structure-function relationships of the antigenicity of mycolic acids in tuberculosis patients. Chem Phys Lipids 2010; 163: 800-808.

[127] Meintjes G, Schoeman H, Morroni C, Wilson D, Maartens G. Patient and provider delay in tuberculosis suspects from communities with a high HIV prevalence in South Africa: A crosssectional study. BMC Infect Dis 2008; 8:72.

[128] Cohen T, Murray M, Wallengren K, Alvarez GG, Samuel EY, Wilson, D. The Prevalence and Drug Sensitivity of Tuberculosis among Patients Dying in Hospital in KwaZulu-Natal, South Africa: A Postmortem Study. PLoS Medicine 2010; 7: 61-68.

[129] Schleicher GK, Feldman C, Vermaak Y, Verschoor JA. Prevalence of anti-mycolic acid antibodies in patients with pulmonary tuberculosis co-infected with HIV. Clin Chem Lab Med 2002; 40: 882-887.

[130] Lemmer Y, Thanyani ST, Vrey PJ, Driver CHS, Venter L, Van Wyngaardt S, Ten Bokum AMC, Ozoemena KI, Pilcher LA, Fernig DG, Stoltz AC, Swai HS, Verschoor JA. Detection of Antimycolic Acid Antibodies by Liposomal Biosensors. In Nejat Düzgüneş, editor. Methods in Enzymology, Burlington: Academic Press, 2009; 464:79-104.

[131] Yuan Y, Zhu Y, Crane DD, Barry III CE. The effect of oxygenated mycolic acid composition on cell wall function and macrophage growth in Mycobacterium tuberculosis. Mol Microbiol 1998; 29: $1449-1458$.

[132] Benadie Y, Deysel M, Siko DGR, Roberts VV, Van Wyngaardt S, Thanyani ST, Sekanka G, Ten Bokum AM, Collett,LA, Grooten J, Baird M S, Verschoor JA. Cholesteroid nature of free mycolic acids from M. tuberculosis. Chem Phys Lipids 2008; 152: 95-103. 
[133] Horváth A, Füst G, Horváth I, Vallus G, Duba J, Harcos P, Proháska L, Rajnavölgyi É, Jánoskuti L, Kovács M, Császár A, Romics L, Karádi I. Anti-cholesterol antibodies (ACHA) in patients with different atherosclerotic vascular diseases and healthy individuals. Atherosclerosis 2001; 156: $185-195$.

[134] Horváth A, Bíró A. Anti-cholesterol antibodies in human sera. Autoimmunity Rev. 2003; 2: 272 $-277$.

[135] Alving CR, Wassef NM. Naturally occurring antibodies to cholesterol: a new theory of LDL cholesterol metabolism. Immunol Today 1999; 20: 362-366.

[136] Füst G, Beck Z, Bánhegyi D, Kocsis J, Bíró A, Prohászka Z. Antibodies against heat shock proteins and cholesterol in HIV infection. Mol Immunol 2005; 42: 79-85.

[137] Zhang Z, Pen Y, Edyvean RG, Banwart SA, Dalgliesch RM, Geoghegan M. Adhesive and conformational behaviour of mycolic acid monolayers. Biochim Biophys Acta 2010; 1798: 18291839 .

[138] De Hostos EL. The coronin family of actin-associated proteins. Trends Cell Biol 1999; 9: 345349.

[139] Gatfield J, Pieters J. Essential role for cholesterol in entry of mycobacteria into macrophages. Science 2000; 2:1647-1650.

[140] De Chastellier C, Thilo L. Cholesterol depletion in Mycobacterium avium infected macrophages overcomes the block in phagosome maturation and leads to the reversible sequestration of viable mycobacteria in phagolysosome-derived autophagic vacuoles. Cell Microbiol 2006; 8:242-56.

[141] Miner MD, Chang JC, Pandey AK, Sassetti CM, Sherman DR. Role of cholesterol in Mycobacterium tuberculosis infection. Indian J Exp Biol 2009; 47: 407-411.

[142] Deghmane A, Soualhine H, Bach H, Sendide K, Itoh S, Tam A, Noubir S, Talal A, Lo R, Toyoshima S, Av-Gay Y, Hmama Z. Lipoamide dehydrogenase mediates retention of coronin-1 on BCG vacuoles, leading to arrest in phagosome maturation. J Cell Sci 2007; 120: 2796-2806.

[143] Jayachandran R, Sundaramurthy V, Combaluzier B, Mueller P, Korf H, Huygen K, Miyazaki T, Albrecht I, Massner J, Pieters J. Survival of mycobacteria in macrophages is mediated by coronin 1dependent activation of calcineurin. Cell 2007; 130: 37-50.

[144] Trimble WS, Grinstein S. TB or not TB: Calcium regulation in mycobacterial survival. Cell 2007; 130: 12-14.

[145] Huynh KK, Gershenzon E, Grinstein S. Cholesterol accumulation by macrophages impairs phagosome maturation. J Biol Chem 2008; 283: 35745-55.

[146] Brzostek A, Pawelczyk J, Rumijowska-Galewicz A, Dziadek B, Dziadek J. Mycobacterium tuberculosis is able to accumulate and utilize cholesterol. J Bacteriol 2009; 191: 6584-6591.

[147] Peyron P, Bordier C, N'Diaye EN, Maridonneau-Parini I. Nonopsonic phagocytosis of Mycobacterium kansasii by human neutrophils depends on cholesterol and is mediated by CR3 associated with glycosylphosphatidylinositolanchored proteins. J Immunol 2000; 165: 5186-5191. 
[148] Pandey AK, Sassetti CM. Mycobacterial persistence requires the utilization of host cholesterol. Proc Natl Acad Sci USA 2008; 105: 4376-4380.

[149] Van der Geize R, Yam K, Heuser T, Wilbrink MH, Hara H, Anderton MC, Sim, E, Dijkhuizen L, Davies JE, Mohn WW, Eltis LD. A gene cluster encoding cholesterol catabolism in a soil actinomycete provides insight into Mycobacterium tuberculosis survival in macrophages. Proc. Natl. Acad. Sci. USA 2007; 104:1947-1952.

[150] Ordway D, Henao-Tamayo M, Orme IM, Gonzalez-Juarrero M. Foamy macrophages within lung granulomas of mice infected with Mycobacterium tuberculosis express molecules characteristic of dendritic cells and anti-apoptotic markers of the TNF receptor-associated factor family. J Immunol 2005; 175: 3873-3881.

[151] Hunter RL, Jagannath C, Actor JK. Pathology of postprimary tuberculosis in humans and mice: contradiction of long-held beliefs. Tuberculosis (Edinb.) 2007; 87: 267-278.

[152] Peyron P, Vaubourgeix J, Poquet Y, Levillain F, Botanch C, Bardou F, Daffé M, Emile J-F, Marchou B, Cardona P-J, De Chastellier C, Altare F. Foamy macrophages from tuberculous patients' granulomas constitute a nutrient-rich reservoir for M. tuberculosis persistence. PLoS Pathog 2008; 4 : e1000204.

[153] Ricote M, Valledor AF, Glass CK. Decoding transcriptional programs regulated by PPARs and LXRs in the macrophage: effects on lipid homeostasis, inflammation, and atherosclerosis. Arterioscler Thromb Vasc Biol 2004; 24: 230-239.

[154] Zelcer N, Tontonoz P. Liver X receptors as integrators of metabolic and inflammatory signaling. J Clin Invest 2006; 116: 607-614.

[155] Zhao C, Dahlman-Wright K. Liver X receptor in cholesterol metabolism. J Endocrinol 2010; 204: $233-240$

[156] Repa JJ, Turley SD, Lobaccaro JA, Medina J, Li L, Lustig K, Shan B, Heyman RA, Dietschy JM, Mangelsdorf DJ. Regulation of absorption and ABC1-mediated efflux of cholesterol by RXR heterodimers. Science 2000;289:1524-1529.

[157] Venkateswaran A, Laffitte BA, Joseph SB, Mak PA, Wilpitz DC, Edwards PA, Tontonoz P. Control of cellular cholesterol efflux by the nuclear oxysterol receptor LXR alpha. Proc Natl Acad Sci USA 2000; 97: 12097-12102.

[158] Korf H, Vander Beken S, Romano M, Steffensen KR, Stijlemans B, Gustafsson J-A, Grooten J, Huygen K. Liver X receptors contribute to the protective immune response against Mycobacterium tuberculosis in mice. J Clin Invest 2009; 119: 1626-1637.

[159] Van der Meer-Janssen YPM, Van Galen J, Batenburg JJ, Helms JB. Lipids in host-pathogen interactions: Pathogens exploit the complexity of the host cell lipidome. Prog Lipid Res 2009; 49: 126.

[160] Dijkstra J, Swartz GM, Raney JJ, Aniagolu J, Toro L, Nacy CA, Green SJ. Interaction of anticholesterol antibodies with human lipoproteins. J Immunol 1996; 157: 2006-2013.

[161] Brig1 M, Brenner MB. CD1: antigen presentation and T cell function. Annu Rev Immunol 2004; 22: 817-890. 
